\title{
Interaction of the mormyrid fish Mormyrus kannume (Forsskål, 1775) reproduction and feeding intensity with the environment in a Nile Delta Canal, Egypt
}

\author{
Elsayed A. Khallaf ${ }^{1}$ and Mohammad M.N. Authman ${ }^{2}$ \\ 1- Zoology Department, Faculty of Science, Minufiya University, \\ Shebeen Alkoom, Egypt \\ 2- Hydrobiology Department, National Research Centre, Dokki 12622, Giza, Egypt
}

\begin{abstract}
The effect of environmental factors on the fish biological parameters and their quantification was investigated in this study during the period from January 2005 to January 2006. Bahr Shebeen Canal is a Nile canal that represents a fishery resource in the Delta of Egypt, where Mormyrus kannume shows a scanty abundance. During the period from of June to September, there was a chance to examine such interaction. The obtained results revealed that the fish spawn over an extended period, from November till May, with two main peaks of spawning activity namely: NovemberDecember and February-April. Consequently, the gonadosomatic index (GSI) could not be correlated significantly with variation in either temperature or photoperiod. In those periods of spawning activity, the fish showed the lowest feeding intensity; i.e., low abundance. This was also quantified mathematically by significant correlations between the seasonal average (excluding winter) of stomachsomatic index (SSI) and either average daily temperature (T) and photoperiod (PP) for females and to a lower extent with males. These relationships were negatively correlated, and more significant among females than males, that was attributed to a higher activity of feeding among females. Also, the fish reproduction and feeding activities were correlated significantly with electrical conductivity and rainfall. This indicated that the fish are subject to the effect of associated environmental parameters interacting with their biology. The susceptibility of this fish species to change in those variables indicates its vulnerability to any adverse climatic change.

The relationship between each of fecundity, egg diameter and gonadosomatic index and the female length or age were also examined and discussed, and the mathematical correlations were presented.
\end{abstract}

Keywords: Mormyrus kannume, environmental effects, reproduction, feeding, ecology, aquatic biology.

\section{INTRODUCTION}

As fish represent a very diverse group, different fish species live in highly diverse environments (Volkoff et al., 2009) and experience natural variation in environmental conditions across spatial and temporal scales, but the speed and severity of these changes have recently increased (van der Sluijs et al., 2011). The earth's atmosphere has warmed significantly over the last 50 years, and most of that warming is believed to have been caused by increased levels of carbon dioxide $\left(\mathrm{CO}_{2}\right)$ and other heat-trapping gases (Albritton et al., 2001; Cicerone et al., 2001, O'Neal, 2002). This warming could in turn raise the temperature of water in streams, thus altering the habitat of freshwater fish (Meisner et al., 1988; Stefan and Preud'homme, 1993; O’Neal, 2002). 
Most fishes are exposed to variations in a wide range of factors, including not only internal factors, such as nutritional/metabolic status and reproductive events but also environmental factors, such as temperature and photoperiod (Volkoff et al., 2009; 2010). Other factors such as water quality are also known to play a major role.

Temperature and photoperiod are two most important factors that influence growth, development and reproduction of aquatic species, including teleost fish (Jin et al., 2010).

Reproduction in fish is rhythmic and timed to guarantee the maximum survival of the offspring. Environmental cues, such as photoperiod and temperature cycles, synchronize the internal timing system that controls breeding (Bromage et al., 2001; Wilkinson et al., 2010; Oliveira et al., 2011). Water temperature does appear to have a more important role in the control of final gamete maturation, ovulation and spawning (Pankhurst et al., 1996). It has a very marked effect on the physiological and biochemical processes in fish, and a raised temperature regime has complex effects on fish reproductive, nerve and endocrine systems (Lukšienė and Svedäng, 1997). Cyclical reproduction of many sub-tropical and tropical fish species are cued by photoperiod and/or temperature (De Vlaming, 1972; Baggerman, 1980; Breton et al., 1980a, 1980b; Billard, 1982; Bromage et al., 2001; Kirschbaum and Schugardt, 2002; Rad et al., 2006). More recently, Taylor et al. (2008) identified important relationships between photoperiod, temperature, growth, maturation and a key hormone involved in the coordination of growth (insulin-like growth factor-I [IGF-I]) in rainbow trout (Oncorhynchus mykiss).

Changes in feeding behavior can be due not only to variations in intrinsic factors such as nutritional/metabolic or reproductive status, but also to changes in environmental factors, such as temperature and photoperiod (Volkoff et al., 2010). Water temperature and photoperiod have potent influences on feed consumption, metabolic rate and energy expenditure, and thus on growth of poikilothermic vertebrates, including fish (Brett, 1979; Elliott, 1982; Dutta, 1994; Bhikajee and Gobin, 1998; Buentello et al., 2000). Photoperiod acts as a synchronizer, regulating the daily endogenous rhythms in fish (Duston and Saunders, 1990; Biswas et al., 2002), fish growth, locomotor activity, metabolic rates, body pigmentation (Gross et al., 1995; Silva-Garcia, 1996; Boeuf and Le Bail, 1999; Biswas and Takeuchi, 2002; Biswas et al., 2002; Trippel and Neil, 2002; El-Sayed and Kawanna, 2004) and is generally accepted as the most important factor synchronizing sexual maturation and reproduction in fish (Bromage et al., 2001; Biswas et al., 2005a).

In the wild, one must note the importance of the synergistic effects of temperature and photoperiod: generally these two factors change concomitantly (Boeuf and Le Bail, 1999). Therefore, the effects of these environmental factors on fish reproduction and feeding warrant thorough investigation.

Mormyrid fishes are considered to be bio-indicators (Hay et al., 1996; Hugueny et al., 1996) as they are among those fishes that react first to environmental changes (Kouamélan et al., 1999). The ability of this family of freshwater fishes as potential rapid indicators of water quality fluctuations has already been studied and indicates enhanced sensitivity when compared with other fish systems (Lewis et al. 1992a, 1992b, 1993, 1994, 1995). So, the mormyrid species Mormyrus kannume was chosen to carry out this study in order to assess the effects of environmental variables on reproduction and food intensity of freshwater fishes.

The mormyrid species Mormyrus kannume (Elephant-snout fish) (Fig. 1a) has a wide distribution in Africa, found in Uganda, Nigeria, Blue Nile and Lake Victoria, and other African lakes and rivers (Hugh Copley, 1958; Scott, 1974; Bishai and 
Khalil, 1997; Khallaf and Authman, 2010). It was reported to be distributed in the River Nile and Lake Nasser, and it was described as a common species but gradually decreasing (El-Etreby, 1985; Bishai and Khalil, 1997). This fish is commonly caught in rapidly flowing water of the River Nile mainly by trammel nets (Latif, 1974). M. kannume spends the day on the bottom, but after nightfall it becomes very active, searching for food, i.e. nocturnal, associated with rocks (Bishai and Khalil, 1997; Khallaf and Authman, 2010). It possesses electric organs lying on either side of the terminal portion of the tail (Hugh Copley, 1958; Webb et al., 1981) and well grown fish can give quite an electrical shock (Boulenger 1907; Bishai and Khalil, 1997). This organ produces an often species-specific discharge for electro-location and communication (Hopkins, 1981). From a reproductive perspective, this fish spawns over rocks, emerging from the mud in deep water (Hugh Copley, 1958; Khallaf and Authman, 2010). M. kannume is a rare species in the commercial catch from Bahr Shebeen Nile Canal (BSC).

BSC (Fig. 1b), is an important irrigation water and fishery resource, running about $80 \mathrm{~km}$ throughout three governorates in the Egyptian Delta. It is a semiindependent water ecosystem from the Nile but connected to it by a major canal (Alrayah Almenoufi) near the Barrage (14 kms north to Cairo), its depth ranges between 2 to $3 \mathrm{~m}$, and its width is about $30 \mathrm{~m}$ (Khallaf, 2002; Khallaf and Authman, 2010).

Previous studies on the reproduction and food of $M$. kannume are scarce, but mainly restricted to the reproductive cycle of the fish (Scott, 1974; El-Etreby, 1985, 1986; Ashour et al., 1990a,b; Zaher et al., 1991; Fawole, 2002; Authman and Khallaf, 2009; Khallaf and Authman, 2009) and stomach contents analysis (Aly, 1993; Soliman, 1994; Hassan, 2007). However, fewer studies dealt with the effect of environmental factors on the fish biology in the Nile system (e.g., Gosse, 1984; Khallaf and Alne-na-ei, 1987, 1993; Khallaf et al., 2003).

Most of the previous studies of the effects of environmental factors on fishes; especially weakly electric fish; were obtained from laboratory investigations (Kirschbaum, 1987; Huber and Bengtson, 1999; Kouamélan et al., 1999; Buentello et al., 2000; Bolliet et al., 2001; Kirschbaum and Schugardt, 2002; El-Sayed and Kawanna, 2004; Schugardt and Kirschbaum, 2004; Biswas et al., 2005a,b; Rad et al., 2006; Taylor et al., 2006; Ballagh et al., 2008; Volkoff et al., 2009, 2010; Jin et al., 2010; Wilkinson et al., 2010; Oliveira et al., 2011). Field investigations of these effects on fish are sparsely.

In Bahr Shebeen canal, M. kannume shows rarity in the commercial catch of this canal most of the year months, but abundant only during June to September, every year, that represents a riddle needing to be solved. Therefore, this study is carried out to examine:

1. The possible reasons of that variation, by investigating the fish reproductive characteristics and feeding intensity interaction with the daily photoperiod and temperature.

2. Quantifying the relationship of the biological parameters with the variation of some environmental factors.

3. Are mormyrids susceptible to the effect of climatic change?

\section{MATERIAL AND METHODS}

\section{(1) Samples collection}

M. kannume specimens were caught monthly by fishermen, using commercial 
fishing gears (trammel nets) during the day, between 6 am to $2 \mathrm{pm}$, at various localities within $25 \mathrm{~km}$ of BSC during consecutive months between January 2005 and January 2006. The fish were transposed back after catching to the laboratory for dissection. In the laboratory, for each fish, the date of capture, total and standard lengths (to the nearest $\mathrm{mm}$ ), and total weight (to the nearest $\mathrm{mg}$ ) were recorded. Fish were dissected out to determine sex and maturity stages. Fish gonads and stomachs were carefully removed, weighed to the nearest $\mathrm{mg}$ and preserved in either Bouin's fluid or $10 \%$ formalin solution for further analysis of reproduction characteristics and in order to preserve the stomach contents for a separate study. In the present study, a total of 134 males ranging from 15.9 to $57.9 \mathrm{~cm}$ in total length and from 31.10 to $1613.00 \mathrm{~g}$ in weight, and a total of 116 females ranging from 15.50 to $52.80 \mathrm{~cm}$ in total length and from 29.80 to $1255.00 \mathrm{~g}$ in weight, were collected.

\section{(2) Reproduction Characteristics}

\section{A- Maturity stages}

This fish species has only one left ovary or testes in the dorsal side of the abdominal cavity, while the second right one is greatly reduced in size. Six maturity stages of ovary and testes were identified and distinguished according to Authman and Khallaf (2009) and Khallaf and Authman (2009) as follows:

Stage I (Immature): Gonads are very small. Ovary is translucent, triangular-shaped and the small sized eggs cannot be distinguished by the naked eye. Testis is very small, thin, narrow thread-like with no sign of development, flattened and transparent.

Stage II (Maturing): Gonads are still small and occupy 1/3 of the body cavity. Ovary is opaque and yellowish or cream-yellow in colour; no oocytes are visible through the ovary wall. Testis is slightly thickened with developing white colour.

Stage III (Nearly-ripe or developing): Gonads begin to develop and occupy 50-60\% of the abdominal cavity. Ovary is yellow in colour and the tiny oocytes are visible through the ovary wall by the naked eye. Testis is broader, thicker, more soft and becomes whitish in colour.

Stage IV (Ripe or highly developing, Pre-spawning): Gonads nearly occupy the entire length of the body cavity. Ovary appears swollen, whitish-creamy or pale yellow in colour and well developed oocytes are visible through the ovary wall. Testis shows maximum development in thickness and width, whitish or creamy in colour and milt extrudes by pressure on the belly.

Stage V (Spawning): Ovary becomes broader, completely turgid, firm and granular. Large translucent, yellow and sticky oocytes are visible through the ovary wall and the eggs can be released with a slight abdominal pressure. Testis is flat and of whitish-creamy opaque colour and the milt discharges by a gentle pressing on the abdomen.

Stage VI (Spent and Atretic): Ovary is severely shrunken, flaccid, reduced in size. Testis is reduced in length, width and thickness and is pinkish bloody in colour and flaccid.

\section{B- The gonadosomatic index (GSI)}

The gonadosomatic index (GSI) was calculated to evaluate the state of maturity of the gonads (Khallaf and Authman, 2010) for each specimen using the following equation:

$$
\mathrm{GSI}=\mathrm{GW} \times 100 / \mathrm{W}
$$

Where GW is weight of gonads (ovary or testis) in grams and W is total body weight of fish in grams. 


\section{C- Fecundity}

Fecundity is the number of mature, or ripe eggs per ovary of fish according to Bagenal (1978) and Bagenal and Tesch (1978). One to three samples per ovary were cut and weighed and then the eggs were counted. This number of eggs is then multiplied by the ratio of ovary weight to that of the sample as follows:

$\mathrm{F}=$ Number of opaque eggs in a sample $\mathrm{X}$ weight of ovary /weight of sample.

Egg count was carried out by the naked eye and fecundity was calculated as the average number of eggs per female fish length or age.

Nineteen ovaries were found with opaque eggs, distributed in the whole period of the present study, and chosen for fecundity analysis.

\section{D- Egg diameter}

Egg diameter was measured to the nearest $\mathrm{mm}$ by an occular micrometer fixed in an eye-piece of a light microscope.

(3) Stomach fullness (stomachsomatic) index (SSI)

Weight of the stomach (mg) was divided by the fish weight $(\mathrm{g})$ and multiplied by a hundred (Khallaf and Alne-na-ei, 1987; Authman, 1990; Khallaf and Authman, 1992).

\section{(4) Ageing}

Fish were assigned to an age-group according to the number of complete annuli on its vertebrae, obtained right behind the skull and right below the dorsal fin, by means of light microscope at $X 4$ magnification. Growth analysis was not the concern of this paper, and data were only used for correlations.

\section{(5) Environmental measurements}

Water temperature $\left({ }^{\circ} \mathrm{C}\right)$ and electrical conductivity $(\mu \mathrm{mhos} / \mathrm{cm})$ of the water column were measured at five stations of BSC, $5 \mathrm{Km}$ each, by using an electronic portable Cond. WTW 330i Meter (WTW Wissenschaftlich-Technische Werkstätten $\mathrm{GmbH}$, Weilheim, Germany). Average daily photoperiod and dark period (hrs.) per month were based upon a national calendar table of sunrise to sunset time. Monthly air temperature $\left({ }^{\circ} \mathrm{C}\right)$ and rainfall $(\mathrm{mm})$ were obtained from national weather records.

(6) Statistical analyses

All statistical analyses were carried out using the Statistical Package for the Social Sciences (SPSS Inc.) program for Windows (Version 17.0).

\section{RESULTS}

\section{Environmental factors}

The monthly averages of environmental factors of BSC are shown in Table (1). For air temperature (AT), the maximum average value was measured during August $\left(37.35{ }^{\circ} \mathrm{C}\right)$, while the lowest average was recorded in December $\left(20.05{ }^{\circ} \mathrm{C}\right)$. The minimum average water temperature (WT) was recorded during January $\left(16.73{ }^{\circ} \mathrm{C}\right)$, while the maximum one was observed during August $\left(28.94{ }^{\circ} \mathrm{C}\right)$. The higher average value of electrical conductivity (EC) was recorded during August $(472 \mu \mathrm{mhos} / \mathrm{cm})$, while the lower $(328 \mu \mathrm{mhos} / \mathrm{cm})$ during March. The monthly variations of rainfall show that the lower values were recorded during June-September period $(0.00 \mathrm{~mm})$ while the higher values during February-April period $(8.50-12.60 \mathrm{~mm})$. The minimum value of photoperiod was recorded during December $(10.26 \mathrm{hrs})$ and the maximum value during June (14.03 hrs). On the other hand, the dark period values fluctuated from 9.97 to 13.74 hrs during June and December, respectively. It is worth to mention that the period of April to November was the highest in average temperature and photoperiod. 
Table 1: Monthly variations of some environmental factors at Bahr Shebeen Canal.

\begin{tabular}{|c|c|c|c|c|c|c|c|c|c|c|c|c|c|c|c|c|c|c|c|c|c|}
\hline \multirow{3}{*}{$\begin{array}{l}\text { Months } \\
\text { Jarnary }\end{array}$} & \multicolumn{6}{|c|}{$\begin{array}{c}\text { Air Temperature }\left({ }^{\circ} \mathrm{C}\right) \\
\text { (AT) }\end{array}$} & \multicolumn{6}{|c|}{$\begin{array}{l}\text { Water Temperature }\left({ }^{\circ} \mathrm{C}\right) \\
(\mathrm{WT})\end{array}$} & \multicolumn{6}{|c|}{$\begin{array}{c}\text { Electrical conductivity } \\
(\mu \mathrm{mbos} / \mathrm{cm})(\mathrm{EC})\end{array}$} & \multirow{3}{*}{$\begin{array}{l}\text { Average } \\
\text { rairfall } \\
\text { (nm) } \\
(\mathrm{R}) \\
080\end{array}$} & \multirow{3}{*}{$\begin{array}{l}\text { Photopenod } \\
\text { (hrs) } \\
\text { (PP) }\end{array}$} & \multirow{3}{*}{$\begin{array}{l}\text { Dark } \\
\text { period } \\
\text { (hrs) } \\
\text { (DP) } \\
13.51\end{array}$} \\
\hline & \multicolumn{3}{|c|}{ Range } & \multirow{2}{*}{$\begin{array}{l}\text { average } \\
22.35\end{array}$} & \multirow{2}{*}{\begin{tabular}{|l|} 
\pm \\
\end{tabular}} & \multirow{2}{*}{$\begin{array}{c}\mathrm{SE} \\
9.25\end{array}$} & \multicolumn{3}{|c|}{ Range } & \multirow{2}{*}{$\begin{array}{l}\text { average } \\
16.73\end{array}$} & \multirow[t]{2}{*}{ \pm} & \multirow{2}{*}{$\frac{S D}{0.07}$} & \multicolumn{3}{|c|}{ Range } & \multirow{2}{*}{$\begin{array}{l}\text { average } \\
398\end{array}$} & \multirow{2}{*}{$\begin{array}{l} \pm \\
\pm\end{array}$} & \multirow{2}{*}{$\frac{S D}{5.56}$} & & & \\
\hline & 13.10 & - & 3160 & & & & 1030 & - & 22.18 & & & & 388 & - & 408 & & & & & & \\
\hline February & 1180 & 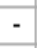 & 36.40 & 24.10 & \pm & 1230 & 1205 & - & 2556 & 17.05 & \pm & 0.00 & 382 & - & 400 & 389 & \pm & 3.48 & 10.80 & 11.13 & 12.87 \\
\hline March & 1330 & - & 39.40 & 26.35 & \pm & 1305 & 12.41 & - & 26.18 & 22.31 & \pm & 0.11 & 322 & - & 346 & 328 & \pm & 6.39 & 12.60 & 12.02 & 11.98 \\
\hline April & 1820 & - & 43.40 & 30.80 & \pm & 1260 & 1620 & - & 30,00 & 26.73 & \pm & 1.85 & 343 & - & 372 & 359 & \pm & 6.84 & 850 & 12.89 & 11.11 \\
\hline May & 1920 & - & 44.40 & 31.80 & \pm & 1260 & 1850 & - & 2800 & 27.15 & \pm & 1.25 & 375 & - & 396 & 385 & \pm & 5.21 & 0.10 & 13.66 & 10.34 \\
\hline June & 23.40 & - & 4800 & 35.70 & \pm & 1230 & 2200 & - & 3020 & 27.68 & \pm & 0.98 & 401 & - & 424 & 412 & \pm & 5.57 & 000 & 14.03 & 997 \\
\hline July & 2730 & - & 4420 & 35.75 & \pm & 8.45 & 2291 & - & 3134 & 28.36 & \pm & 0.69 & 429 & - & 453 & 441 & \pm & 5.96 & 000 & 13.87 & 10.13 \\
\hline Auqust & 2830 & - & 46.40 & 37.35 & \pm & 9.05 & 2336 & - & 31.75 & 28.94 & \pm & 0.71 & 459 & - & 485 & 472 & \pm & 6.38 & 0,00 & 13.21 & 10.79 \\
\hline September & 2690 & - & 45.70 & 36.30 & \pm & 9.40 & 20.74 & - & 28.76 & 26.58 & \pm & 0.16 & 450 & - & 475 & 462 & \pm & 6.25 & 000 & 12.34 & 11.66 \\
\hline October & 2690 & - & 4190 & 34.35 & \pm & 7.45 & 1890 & - & 26.13 & 24.10 & \pm & 0.10 & 441 & - & 466 & 45 & \pm & 6.37 & 0.70 & 11.48 & 12.52 \\
\hline November & 14.10 & - & 3530 & 24.70 & \pm & 1060 & 15.11 & - & 2458 & 19.37 & \pm & 0.08 & 419 & - & 443 & 430 & \pm & 6.06 & 380 & 10.66 & 13.34 \\
\hline December & 1150 & - & 2860 & 20.05 & \pm & 8.55 & 1121 & - & 19.12 & 16.93 & \pm & 0.04 & 398 & - & 420 & 409 & \pm & 5.75 & 260 & 10.26 & 13.74 \\
\hline
\end{tabular}

$\mathrm{SE}=$ standard error.

$\mathrm{SD}=$ standard deviation .

\section{Monthly variation of maturity stages, GSI and SSI of M. kannume}

The variation of maturity stages is shown in Table (2). From that Table, it appears that stages of different maturity grades occur in various months. However, stages IV and V were chosen because they represent the state of higher spawning activity (Fig. 2). From that figure, it is noted that males gonads of stages IV and V were conspicuously present during February to April and November-December periods, where males with stage VI gonads were present in January, May and AugustOctober.
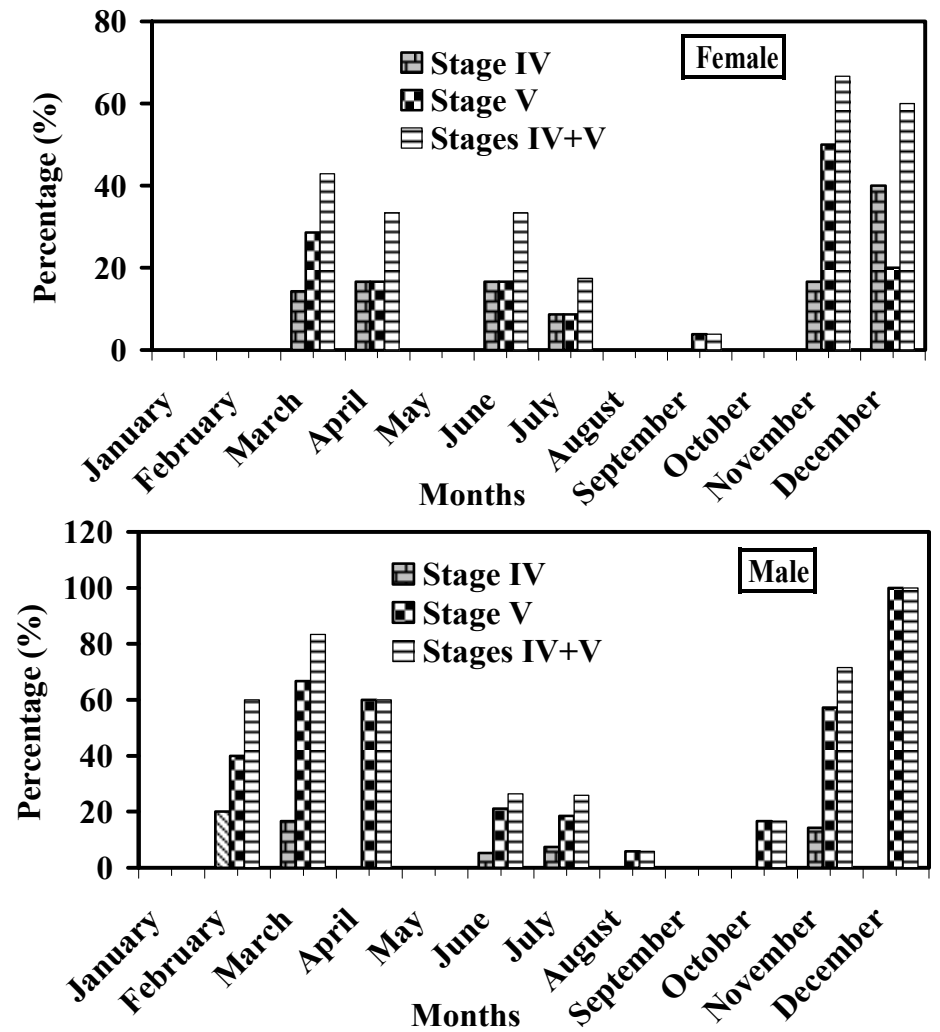

Fig. 2: Monthly variations of the percentage of occurrence of maturity stages IV, V and IV+V of males and females of M. kannume. 
Table 2: Monthly frequency distribution of gonad maturity stages of males and females M. kannume from Bahr Shebeen Nilotic canal.

\begin{tabular}{|c|c|c|c|c|c|c|c|c|c|}
\hline \multirow{3}{*}{ Month } & \multicolumn{9}{|c|}{ Male } \\
\hline & \multirow{2}{*}{$\begin{array}{l}\text { No. of } \\
\text { fishes }\end{array}$} & \multirow{2}{*}{$\begin{array}{l}\text { Total length } \\
(\mathrm{cm})\end{array}$} & \multicolumn{7}{|c|}{$\%$ Maturity Stages } \\
\hline & & & $\bar{I}$ & II & III & IV & $\mathrm{V}$ & $\mathrm{IV}+\mathrm{V}$ & VI \\
\hline January & 5 & $19.0-31.5$ & 40.00 & 20.00 & 20.00 & 0.00 & 0.00 & 0.00 & 20.00 \\
\hline February & 5 & $23.8-42.5$ & 20.00 & 0.00 & 20.00 & 20.00 & 40.00 & 60.00 & 0.00 \\
\hline March & 6 & $31.5-46.4$ & 0.00 & 0.00 & 16.67 & 16.67 & 66.67 & 83.34 & 0.00 \\
\hline April & 5 & $19.0-42.5$ & 20.00 & 20.00 & 0.00 & 0.00 & 60.00 & 60.00 & 0.00 \\
\hline May & 7 & $21.0-31.8$ & 71.43 & 14.29 & 0.00 & 0.00 & 0.00 & 0.00 & 14.29 \\
\hline June & 19 & $21.3-50.7$ & 63.16 & 5.26 & 5.26 & 5.26 & 21.05 & 26.31 & 0.00 \\
\hline July & 27 & $21.0-56.5$ & 74.07 & 0.00 & 0.00 & 7.41 & 18.52 & 25.93 & 0.00 \\
\hline August & 17 & $20.9-45.0$ & 29.41 & 52.94 & 0.00 & 0.00 & 5.88 & 5.88 & 11.76 \\
\hline September & 21 & $15.9-37.8$ & 52.38 & 28.57 & 9.52 & 0.00 & 0.00 & 0.00 & 9.52 \\
\hline October & 6 & $21.6-42.3$ & 33.33 & 16.67 & 0.00 & 0.00 & 16.67 & 16.67 & 33.33 \\
\hline November & 7 & $29.8-55.5$ & 14.29 & 0.00 & 14.29 & 14.29 & 57.14 & 71.43 & 0.00 \\
\hline December & 9 & $45.0-57.9$ & 0.00 & 0.00 & 0.00 & 0.00 & 100.00 & 100.00 & 0.00 \\
\hline \multirow[t]{2}{*}{ Total } & 134 & & & & & & & & \\
\hline & \multicolumn{9}{|c|}{ Female } \\
\hline \multirow[t]{2}{*}{ Month } & No. of & Total length & \multicolumn{7}{|c|}{$\%$ Maturity Stages } \\
\hline & fishes & $(\mathrm{cm})$ & $\mathrm{I}$ & II & III & IV & $\mathrm{V}$ & $\mathrm{IV}+\mathrm{V}$ & VI \\
\hline January & 5 & $20.7-33.6$ & 40.00 & 40.00 & 0.00 & 0.00 & 0.00 & 0.00 & 20.00 \\
\hline February & 5 & $23.1-33.5$ & 40.00 & 40.00 & 0.00 & 0.00 & 0.00 & 0.00 & 20.00 \\
\hline March & 7 & $21.1-38.2$ & 28.57 & 28.57 & 0.00 & 14.29 & 28.57 & 42.86 & 0.00 \\
\hline April & 6 & $22.7-40.2$ & 33.33 & 33.33 & 0.00 & 16.67 & 16.67 & 33.34 & 0.00 \\
\hline May & 5 & $26.1-35.4$ & 40.00 & 40.00 & 0.00 & 0.00 & 0.00 & 0.00 & 20.00 \\
\hline June & 6 & $21.1-37.9$ & 33.33 & 33.33 & 0.00 & 16.67 & 16.67 & 33.34 & 0.00 \\
\hline July & 23 & $20.7-43.0$ & 52.17 & 26.09 & 4.35 & 8.70 & 8.70 & 17.40 & 0.00 \\
\hline August & 11 & $21.0-33.3$ & 54.55 & 27.27 & 0.00 & 0.00 & 0.00 & 0.00 & 18.18 \\
\hline September & 26 & $15.5-41.0$ & 57.69 & 11.54 & 23.08 & 0.00 & 3.85 & 3.85 & 3.85 \\
\hline October & 11 & $21.5-33.5$ & 54.55 & 18.18 & 18.18 & 0.00 & 0.00 & 0.00 & 9.09 \\
\hline November & 6 & $21.6-43.7$ & 33.33 & 0.00 & 0.00 & 16.67 & 50.00 & 66.67 & 0.00 \\
\hline December & 5 & $28.1-52.8$ & 0.00 & 20.00 & 20.00 & 40.00 & 20.00 & 60.00 & 0.00 \\
\hline Total & 116 & & & & & & & & \\
\hline
\end{tabular}

* Maturity stages (After Authman and Khallaf, 2009, and Khallaf and Authman, 2009): I Immature; II Mature; III Developing, IV Highly developing; V Spawning; VI Spent.

On the other hand, females with stages IV and V gonads were high during March-April, June-July, September and November-December. Females with stage VI gonads were shown to appear in the periods of January-February, May, and August-October. It is worth to mention that, the relationships between monthly stages IV and V of fish males and females and the different environmental factors are not significantly correlated.

GSI and SSI varied monthly for both males and females, as indicated in table (3) and fig. (3).

Thus, males GSI values were comparable but with slightly higher activity during February-April and November-December periods. On the other hand, females GSI values peaked conspicuously in March, in addition to slightly higher values in June and NovemberDecember period.

On considering the SSI, males have their highest feeding intensity during the months of May to September, with a similar higher activity during January. In those months, males GSI values were low as compared to the rest of the year months. However, females SSI values were comparable, but showed higher values in the period of June to October, while GSI values were lower during July to October months.

When sex ratio was taken into account (Table 2), males and females were comparable during the year months, but males outnumbered females during May-August and December. 
The monthly average of males GSI was significantly negatively correlated with male SSI (Table 3) $(\mathrm{r}=-0.7682, F=14.4018, P<0.01)$. It was also found that, male GSI was significantly correlated with female GSI $(\mathrm{r}=0.7187, F=10.6817, P<0.01)$. On the other hand, no correlation could be obtained between female GSI and SSI $(r=0.0378, F=0.0143, \mathrm{P}>0.05)$.

Table 3: Monthly variation of gonadosomatic (GSI) and stomachsomatic (SSI) indices for males and females M. kannume from Bahr Shebeen Nilotic canal.

\begin{tabular}{|c|c|c|c|c|c|c|c|c|c|c|}
\hline \multirow{3}{*}{ Months } & \multicolumn{5}{|c|}{ Male } & \multicolumn{5}{|c|}{ Female } \\
\hline & \multirow{2}{*}{ No. of fishes } & \multicolumn{2}{|c|}{ GSI } & \multicolumn{2}{|r|}{ SSI } & \multirow{2}{*}{$\begin{array}{l}\text { No. of } \\
\text { fishes }\end{array}$} & \multicolumn{2}{|c|}{ GSI } & \multicolumn{2}{|r|}{ SSI } \\
\hline & & Range & Mean \pm SE. & Range & $\operatorname{Mean} \pm \mathbf{S E}$ & & Range & Mean \pm S.E. & Range & Mean \pm S.E. \\
\hline January & 5 & $0.027-0.241$ & $0.086 \pm 0.039^{n}$ & $1.160-3.950$ & $2.834 \pm 0.535^{\mathrm{kc}}$ & 5 & $0.132-0.509$ & $0.287 \pm 0.068^{n}$ & $1.160-5.560$ & $3.468 \pm 0.848^{\prime \prime}$ \\
\hline February & 5 & $0.083-0.461$ & $0.293 \pm 0.071^{\mathrm{kal}}$ & $1.030-3.480$ & $2.138 \pm 0.439^{4 k 6}$ & 5 & $0.119-0.690$ & $0.348 \pm 0.101^{A}$ & $1.13-3.67$ & $2.048 \pm 0.497^{\text {the }}$ \\
\hline March & 6 & $0.234-0.529$ & $0.363 \pm 0.052^{\mathrm{d}}$ & $0.922-2.000$ & $1.270 \pm 0.169^{a}$ & 7 & $0.069-17.918$ & $7.596 \pm 2.813^{\mathrm{b}}$ & $1.63-5.634$ & $2.825 \pm 0.696^{\mathrm{kcd}}$ \\
\hline April & 5 & $0.048-0.521$ & $0.271 \pm 0.095^{\mathrm{bol}}$ & $0.830-1.508$ & $1.204 \pm 0.131^{\star}$ & 6 & $0.121-6.947$ & $3.661 \pm 1.127^{n}$ & $1.016-3.810$ & $2.447 \pm 0.466^{\text {atcal }}$ \\
\hline May & 7 & $0.022-0.193$ & $0.141 \pm 0.023^{A}$ & $1.027-4.286$ & $3.195 \pm 0.413^{6}$ & 5 & $0.209-0.922$ & $0.406 \pm 0.130^{\star}$ & $0.667-2.976$ & $1.687 \pm 0.406^{\mathrm{Ab}}$ \\
\hline June & 19 & $0.023-0.765$ & $0.200 \pm 0.051^{\text {alcod }}$ & $0.896-6.579$ & $3.061 \pm 0.361^{\mathrm{k}}$ & 6 & $0.184-9.058$ & $1.787 \pm 1.458^{\circ}$ & $1.714-5.634$ & $3.473 \pm 0.668^{d}$ \\
\hline July & 27 & $0.016-0.530$ & $0.130 \pm 0.031^{4 b}$ & $0.966-5.385$ & $3.00 \pm 0.255^{\mathrm{kc}}$ & 23 & $0.118-4.428$ & $0.486 \pm 0.196^{\circ}$ & $1.205-5.556$ & $3.183 \pm 0.222^{\mathrm{cd}}$ \\
\hline August & 17 & $0.031-0.557$ & $0.134 \pm 0.031^{\text {ab }}$ & $0.857-3.810$ & $2.165 \pm 0.239^{a b c}$ & 11 & $0.152-0.375$ & $0.235 \pm 0.019^{*}$ & $1.875-4.118$ & $2.923 \pm 0.250^{\mathrm{k}: \mathrm{d}}$ \\
\hline September & 21 & $0.008-0.244$ & $0.097 \pm 0.015^{a}$ & $1.136-5.764$ & $2.793 \pm 0.285^{\mathrm{k}}$ & 26 & $0.059-1.766$ & $0.277 \pm 0.062^{\mathrm{a}}$ & $0.667-5.714$ & $2832 \pm 0.226^{\mathrm{kad}}$ \\
\hline October & 6 & $0.040-0.387$ & $0.161 \pm 0.057^{\text {alc }}$ & $1.122-3.500$ & $1.811 \pm 0.365^{\mathrm{ab}}$ & 11 & $0.146-0.307$ & $0.217 \pm 0.018^{a}$ & $1.194-3.478$ & $2.462 \pm 0.211^{\text {aba }}$ \\
\hline Nove mber & 7 & $0.036-0.448$ & $0.268 \pm 0.060^{\mathrm{bal}}$ & $0.560-1.442$ & $1.073 \pm 0.101^{\wedge}$ & 6 & $0.127-2.273$ & $1.591 \pm 0.349^{\circ}$ & $0.880-3.947$ & $1.803 \pm 0.499^{\mathrm{alc}}$ \\
\hline Decermber & 9 & $0.172-0.439$ & $0.310 \pm 0.031^{\mathrm{al}}$ & $0.868-1.602$ & $1.146 \pm 0.098^{n}$ & 5 & $0.069-2.504$ & $1.602 \pm 0.457^{A}$ & $0.857-1.736$ & $1.327 \pm 0.176^{\star}$ \\
\hline Total & 134 & & & & & 116 & & & & \\
\hline$F$-ratio (Sig.) & & & $3.66^{* * *}(0.000)$ & & $4.856 * *(0.000)$ & & & $2.62 * *(0.005)$ & & $2.381^{*}(0.011)$ \\
\hline \multicolumn{2}{|l|}{ Rehationshị } & $\mathbf{a}$ & \multicolumn{2}{|l|}{$\mathbf{b}$} & SE (b) & $\mathbf{r}$ & $\mathbf{r}^{2}$ & SEE & $F$-value & (Sig.) \\
\hline \multicolumn{2}{|c|}{$\operatorname{MGSI}(X)$ vs. MSSI $(Y)$} & 3.5360 & \multicolumn{2}{|c|}{-6.8294} & 1.7996 & 07682 & 0.5902 & 0.5538 & 14.4018 & $0.004^{* *}$ \\
\hline \multirow{3}{*}{\multicolumn{2}{|c|}{$\begin{array}{l}\operatorname{MGSI}(X) \text { vs. FGSI }(Y) \\
\text { FGSI }(X) \text { vs. FSSI }(Y) \\
\text { FGSI }(X) \text { vs. MGSI }(Y)\end{array}$}} & -1.8909 & \multirow{3}{*}{\multicolumn{2}{|c|}{$\begin{array}{l}16.7889 \\
0.0123 \\
0.0308\end{array}$}} & 5.1369 & $0.718 ?$ & 0.5165 & 1.5807 & 10.6817 & $0.009^{*}$ \\
\hline & & 2.5211 & & & 0.1025 & 0.0378 & 0.0014 & 0.7371 & 0.0143 & 0.907 \\
\hline & & 0.1570 & & & 0.0094 & 0.7187 & 0.5165 & 0.0677 & 10.6817 & $0.009^{\circ}$ \\
\hline
\end{tabular}

S.E. $=$ standard error.

* Significant $(P<0.05)$.

a $=$ Constant

(Sig. $)=$ significance level.
$* *$ Highly significant $(P<0.01) . \quad(X)=$ Independent variable. $(Y)=$ Dependent variable.

SE (b) = Standard error of " $b "$.

Cor each parameter are not significantly different $(P>0.05)$; otherwise, they do (Duncan's multiple range test, 1955).
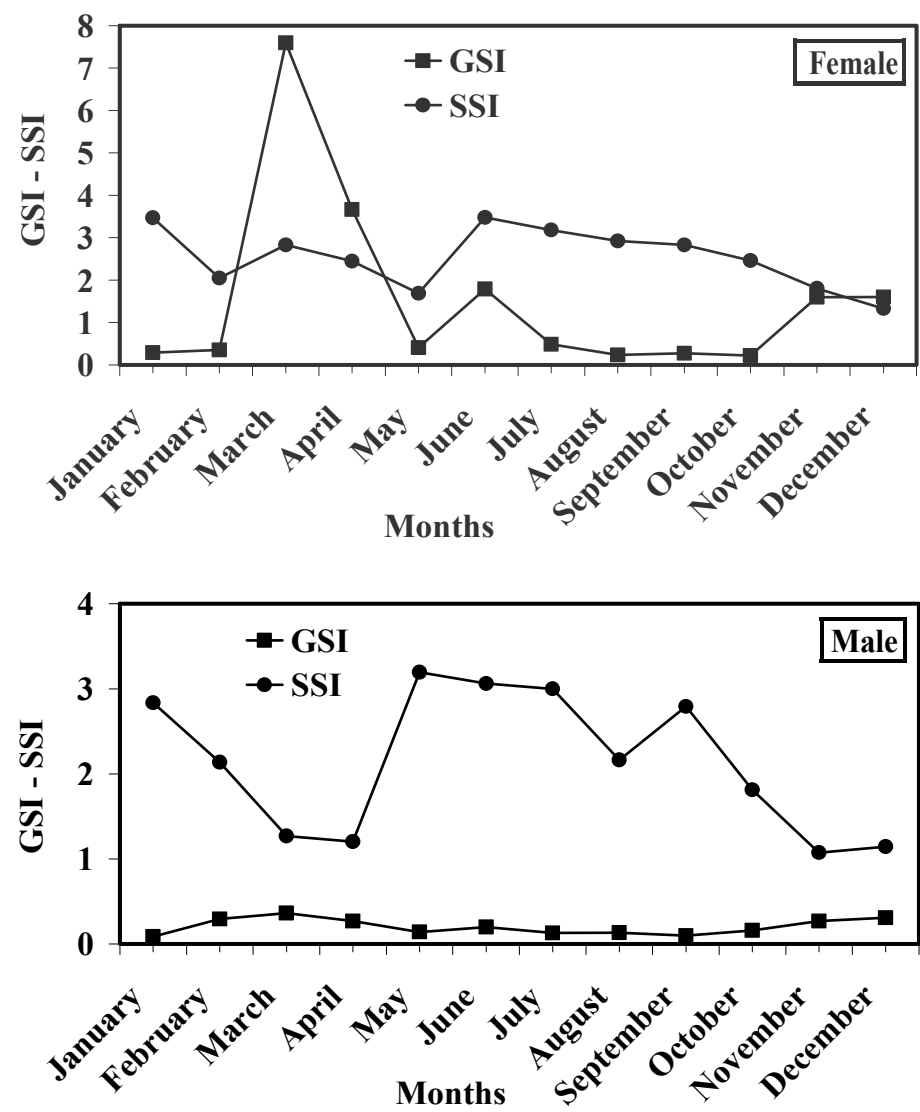

Fig. 3: Monthly variations of gonadosomatic index (GSI) and stomachsomatic index (SSI) of males and females of $M$. kannume. 


\section{Absolute fecundity and egg diameter}

Variation of absolute fecundity (Table 4) indicates that its values ranged between 393 and 10078 with an average of 4288 eggs. Fecundity, as number of opaque eggs, variation correlates (Table 4) significantly with the variation of either fish total length $(\mathrm{r}=0.8047$, $F=12.8581, P<0.01)$ or age $(\mathrm{r}=0.9331, F=33.6853, P<0.01)$ (Fig. 4B). However, there are insignificant correlations between the fish total length, but over the range of $37 \mathrm{~cm}$, and GSI $(\mathrm{r}=0.6906, F=2.7354, \mathrm{P}>0.05)$ and egg diameter $(\mathrm{r}=0.7961, F=5.1929, P>0.05)$ of the fecund fish (Table 4).

The age of M. kannume fecund fish correlates insignificantly with the variation of GSI $(\mathrm{r}=0.6666, F=3.9976, P>0.05)$ and significantly with the variation of egg diameter ( $\mathrm{r}=$ $0.8677, F=15.2335, P<0.05$ ) (Figs. 4A, 4C).

Table 4: Variations of gonadosomatic index (GSI), fecundity (F) and egg diameter (ED) with length and age of the fecund M. kannume fish

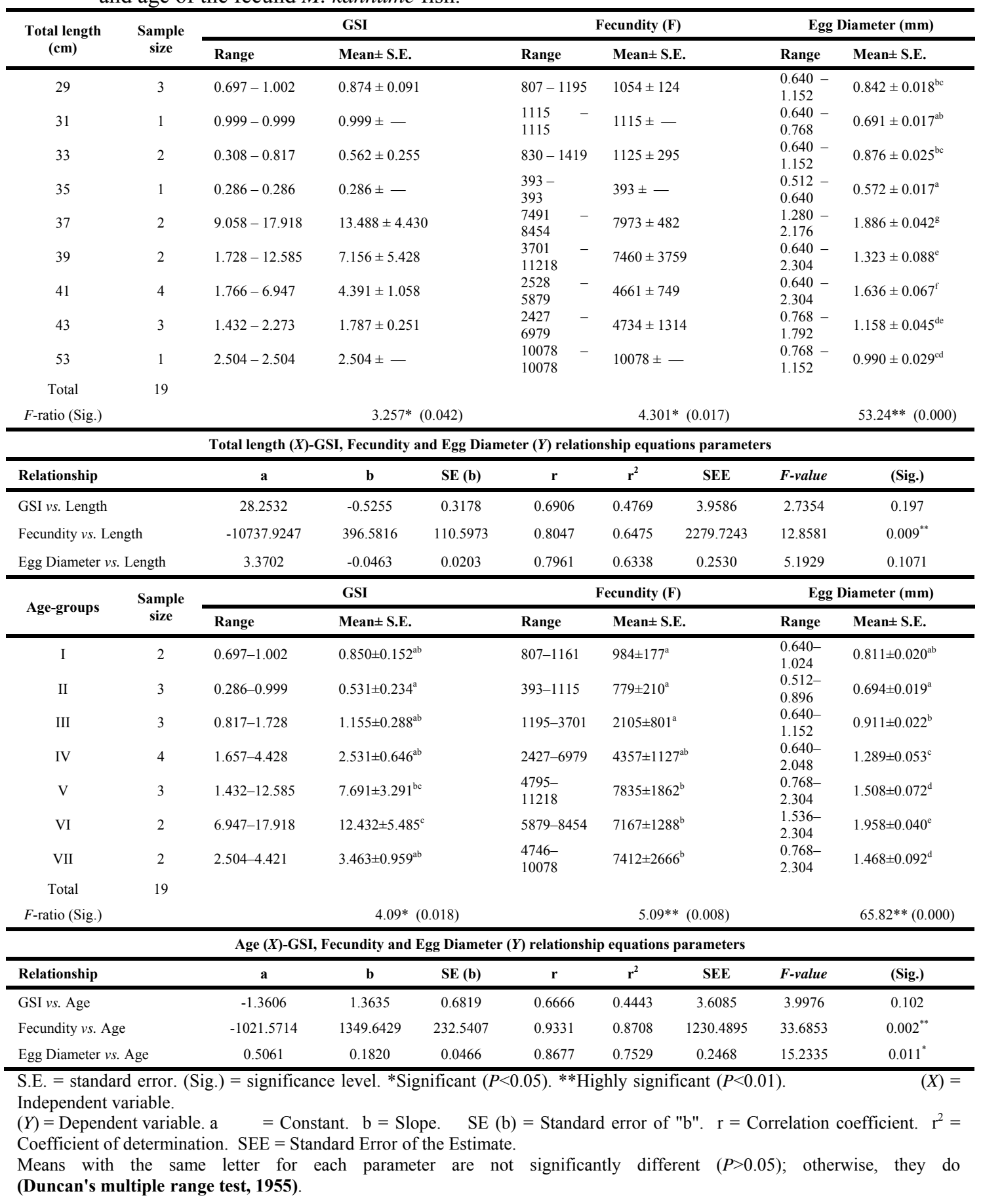



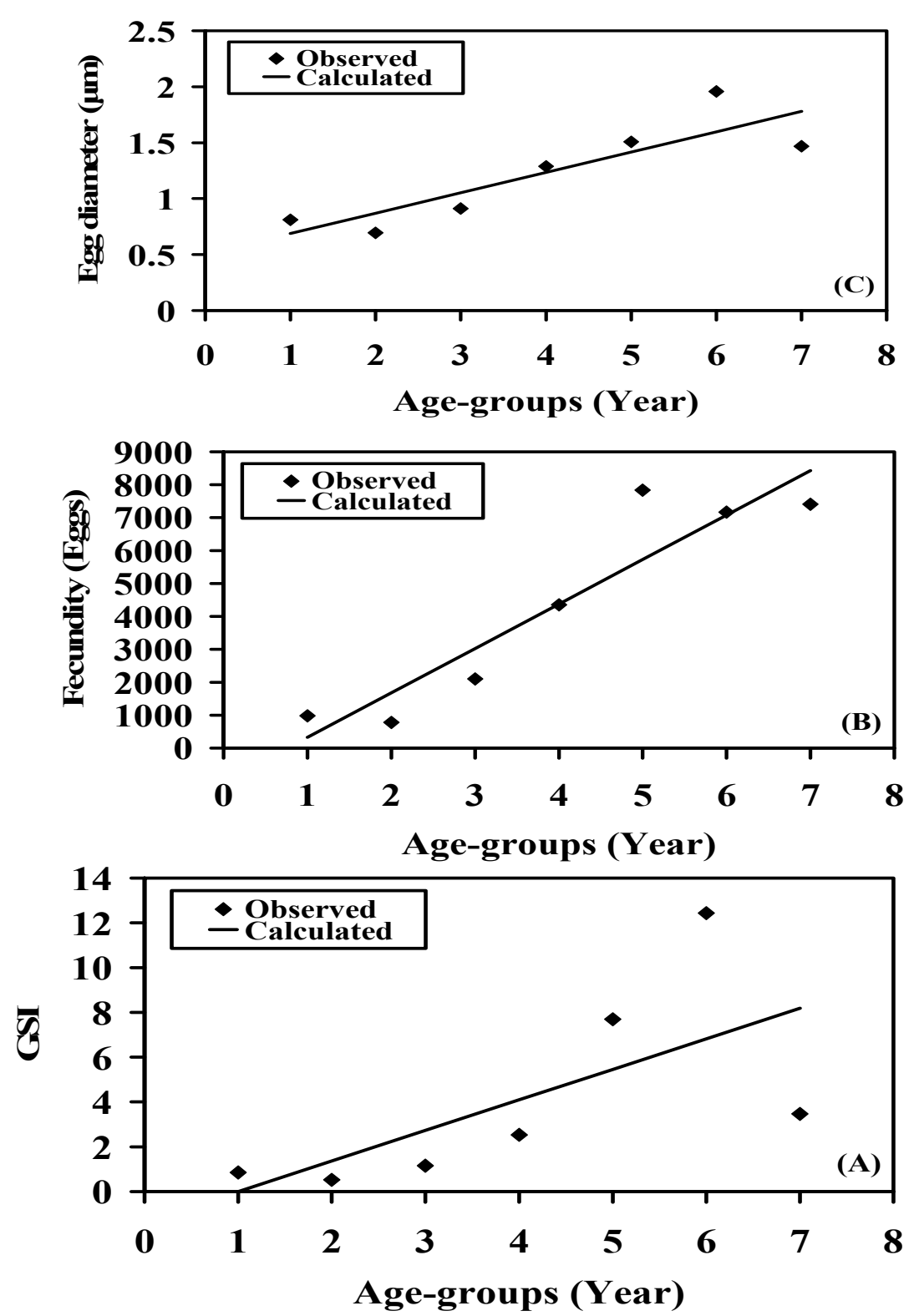

Fig. 4: (A) Variations of GSI, (B) fecundity and (C) egg diameter with age-groups variations of $M$. kannume.

\section{Interaction of monthly average GSI, SSI, fecundity (F) and egg diameter (ED) with environmental factors of BSC}

There was no clear trend in the variation of those biological parameters and either photoperiod or temperature. The regression of the fish GSI against air or water temperature or daily light and dark periods, revealed insignificant correlation $(\mathrm{P}>0.05)$, while the male SSI correlated significantly $(\mathrm{P}<0.05)$ with these environmental factors. However, on considering multivariate analyses (Table 5), those biological parameters correlated significantly $(\mathrm{P}<0.05)$ and in many cases highly significantly $(\mathrm{P}<0.01)$ with these environmental factors, in addition to conductivity and rainfall. 
Table 5: Univariate and multivariate regression analysis of gonadosomatic (GSI) and stomachsomatic (SSI) indices [dependent variable, Y] against air (AT) and water (WT) temperature, electrical conductivity (EC), rainfall (R), daily photoperiod (PP) and dark period (DP) [independent variable, $\mathrm{X}]$.

\begin{tabular}{|c|c|c|c|c|c|c|c|c|c|}
\hline \multicolumn{10}{|c|}{ Univariate regression analysis $(\mathrm{Y}=\mathbf{a}+\mathbf{b X})$} \\
\hline Interaction & $\mathbf{a}$ & $\mathbf{b}$ & SE (b) & $\mathbf{r}$ & $\mathbf{r}^{2}$ & SEE & $F$ & \multicolumn{2}{|c|}{$\boldsymbol{P}$} \\
\hline MGSI vs. EC & 0.7782 & -0.0014 & 0.0005 & -0.645 & 0.416 & 0.074 & 7.129 & \multicolumn{2}{|c|}{$0.024^{*}$} \\
\hline MGSI vs. R & 0.1497 & 0.0165 & 0.0035 & 0.824 & 0.679 & 0.055 & 21.103 & \multicolumn{2}{|c|}{$0.001^{* *}$} \\
\hline MSSI vs. R & 2.4926 & -0.1060 & 0.0450 & -0.597 & 0.357 & 0.694 & 5.542 & \multicolumn{2}{|c|}{$0.040^{*}$} \\
\hline FGSI vs. EC & 17.1936 & -0.0380 & 0.0105 & -0.753 & 0.568 & 1.495 & 13.124 & \multicolumn{2}{|c|}{$0.005^{* *}$} \\
\hline FGSI vs. R & 0.4240 & 0.3360 & 0.1024 & 0.720 & 0.518 & 1.578 & 10.761 & \multicolumn{2}{|c|}{$0.008^{* *}$} \\
\hline \multicolumn{10}{|c|}{ Multivariate regression analysis $\left(Y=a+b_{1} X_{1}+b_{2} X_{2}+b_{3} X_{3} \ldots\right.$ etc. $)$} \\
\hline Interaction & $\mathbf{a}$ & $\mathbf{b}_{1}$ & $\mathbf{b}_{2}$ & $\mathbf{b}_{3}$ & $\mathbf{r}$ & $\mathbf{r}^{2}$ & SEE & $\boldsymbol{F}$ & $\boldsymbol{P}$ \\
\hline MGSI vs. AT and R & 0.2507 & -0.0031 & 0.0145 & - & 0.844 & 0.712 & 0.055 & 11.126 & $0.004^{* *}$ \\
\hline MGSI vs. WT and R & 0.2071 & -0.0023 & 0.0155 & - & 0.831 & 0.691 & 0.057 & 10.048 & $0.005^{* *}$ \\
\hline MGSI vs. EC and R & 0.1960 & -0.0001 & 0.0157 & - & 0.824 & 0.680 & 0.058 & 9.542 & $0.006^{* *}$ \\
\hline MGSI vs. AT and WT and R & 0.2476 & -0.0102 & 0.0093 & 0.0137 & 0.859 & 0.739 & 0.056 & 7.533 & $0.010^{*}$ \\
\hline MGSI vs. WT and EC and R & 0.2529 & -0.0023 & -0.0001 & 0.0148 & 0.832 & 0.692 & 0.060 & 5.983 & $0.019^{*}$ \\
\hline MGSI vs. WT and R and PP & 0.2103 & -0.0022 & 0.0156 & -0.0006 & 0.831 & 0.691 & 0.061 & 5.955 & $0.020^{*}$ \\
\hline MGSI vs. WT and R and DP & 0.1966 & -0.0022 & 0.0156 & 0.0006 & 0.831 & 0.691 & 0.061 & 5.955 & $0.020^{*}$ \\
\hline MSSI vs. AT and WT and PP & -5.8161 & 0.1988 & -0.4279 & 0.9904 & 0.784 & 0.615 & 0.600 & 4.253 & $0.045^{*}$ \\
\hline MSSI vs. AT and WT and DP & 17.9526 & 0.1988 & -0.4279 & -0.9904 & 0.784 & 0.615 & 0.600 & 4.253 & $0.045^{*}$ \\
\hline MSSI vs. WT and EC and PP & -10.5926 & -0.2690 & 0.0114 & 1.1807 & 0.784 & 0.614 & 0.601 & 4.243 & $0.045^{*}$ \\
\hline MSSI vs. WT and EC and DP & 17.7452 & -0.2690 & 0.0114 & -1.1807 & 0.784 & 0.614 & 0.601 & 4.243 & $0.045^{*}$ \\
\hline MSSI vs. WT and R and PP & -3.6874 & -0.2157 & -0.1161 & 0.9269 & 0.852 & 0.726 & 0.506 & 7.073 & $0.012^{*}$ \\
\hline MSSI vs. WT and R and DP & 18.5579 & -0.2157 & -0.1161 & -0.9269 & 0.852 & 0.726 & 0.506 & 7.073 & $0.012^{*}$ \\
\hline MGSI vs. MSSI and AT & 0.4668 & -0.0735 & -0.0035 & - & 0.794 & 0.631 & 0.062 & 7.695 & $0.011^{*}$ \\
\hline MGSI vs. MSSI and WT & 0.4323 & -0.0808 & -0.0023 & - & 0.776 & 0.602 & 0.065 & 6.816 & $0.016^{*}$ \\
\hline MGSI vs. MSSI and AT and WT & 0.4482 & -0.0692 & -0.0122 & 0.0115 & 0.820 & 0.673 & 0.062 & 5.482 & $0.024^{*}$ \\
\hline MGSI vs. MSSI and AT and EC & 0.7666 & -0.0710 & -0.0001 & -0.0010 & 0.886 & 0.784 & 0.051 & 9.693 & $0.005^{* *}$ \\
\hline MGSI vs. MSSI and AT and R & 0.3100 & -0.0446 & -0.0015 & 0.0108 & 0.897 & 0.804 & 0.048 & 10.969 & $0.003^{* *}$ \\
\hline MGSI vs. MSSI and AT and PP & 0.1180 & -0.0909 & -0.0119 & 0.0525 & 0.898 & 0.807 & 0.048 & 11.140 & $0.003^{* *}$ \\
\hline MGSI vs. MSSI and AT and DP & 1.3769 & -0.0909 & -0.0119 & -0.0525 & 0.898 & 0.807 & 0.048 & 11.140 & $0.003^{* *}$ \\
\hline MGSI vs. MSSI and WT and EC & 0.7718 & -0.0703 & -0.0005 & -0.0010 & 0.886 & 0.785 & 0.051 & 9.722 & $0.005^{* *}$ \\
\hline MGSI vs. MSSI and WT and R & 0.2814 & -0.0474 & -0.0005 & 0.0112 & 0.893 & 0.798 & 0.049 & 10.523 & $0.004^{* *}$ \\
\hline MGSI vs. MSSI and WT and PP & -0.2324 & -0.1206 & -0.0295 & 0.1140 & 0.955 & 0.912 & 0.032 & 27.768 & $0.0001^{* *}$ \\
\hline MGSI vs. MSSI and WT and DP & 2.5036 & -0.1206 & -0.0295 & -0.1140 & 0.955 & 0.912 & 0.032 & 27.768 & $0.0001^{* *}$ \\
\hline MGSI vs. FGSI and AT & 0.3480 & 0.0266 & -0.0062 & - & 0.821 & 0.674 & 0.059 & 9.294 & $0.006^{* *}$ \\
\hline MGSI vs. FGSI and WT & 0.3349 & 0.0301 & -0.0075 & - & 0.817 & 0.668 & 0.059 & 9.046 & $0.007^{* *}$ \\
\hline MGSI vs. FGSI and AT and WT & 0.3476 & 0.0276 & -0.0045 & -0.0022 & 0.822 & 0.675 & 0.062 & 5.536 & $0.024^{*}$ \\
\hline MGSI vs. FGSI and AT and EC & 0.2651 & 0.0297 & -0.0067 & 0.0002 & 0.823 & 0.677 & 0.062 & 5.599 & $0.023^{*}$ \\
\hline MGSI vs. FGSI and AT and R & 0.2666 & 0.0136 & -0.0038 & 0.0010 & 0.871 & 0.759 & 0.053 & 8.405 & $0.007^{* *}$ \\
\hline MGSI vs. FGSI and AT and PP & 0.3391 & 0.0264 & -0.0064 & 0.0014 & 0.821 & 0.674 & 0.062 & 5.511 & $0.024^{*}$ \\
\hline MGSI vs. FGSI and AT and DP & 0.3736 & 0.0264 & -0.0064 & -0.0014 & 0.821 & 0.674 & 0.062 & 5.511 & $0.024^{*}$ \\
\hline MGSI vs. FGSI and WT and EC & 0.3392 & 0.0299 & -0.0075 & -0.00001 & 0.817 & 0.668 & 0.063 & 5.361 & $0.026^{*}$ \\
\hline MGSI vs. FGSI and WT and R & 0.2492 & 0.0158 & -0.0043 & 0.0095 & 0.865 & 0.747 & 0.055 & 7.889 & $0.009^{* *}$ \\
\hline MGSI vs. FGSI and WT and PP & 0.2512 & 0.0297 & -0.0112 & 0.0141 & 0.821 & 0.674 & 0.062 & 5.515 & $0.024^{*}$ \\
\hline MGSI vs. FGSI and WT and DP & 0.5895 & 0.0297 & -0.0112 & -0.0141 & 0.821 & 0.674 & 0.062 & 5.515 & $0.024^{*}$ \\
\hline FGSI vs. AT and EC & 17.2194 & 0.0724 & -0.0434 & - & 0.774 & 0.599 & 1.518 & 6.710 & $0.017^{*}$ \\
\hline FGSI vs. AT and R & -1.1661 & 0.0496 & 0.3674 & - & 0.731 & 0.534 & 1.637 & 5.148 & $0.032^{*}$ \\
\hline FGSI vs. WT and EC & 16.3096 & 0.0884 & -0.0409 & - & 0.776 & 0.603 & 1.511 & 6.822 & $0.016^{*}$ \\
\hline FGSI vs. WT and R & -2.6679 & 0.1246 & 0.3855 & - & 0.764 & 0.583 & 1.547 & 6.296 & $0.019^{*}$ \\
\hline FGSI vs. AT and WT and R & -1.3357 & -0.3365 & 0.5058 & 0.3237 & 0.824 & 0.678 & 1.442 & 5.618 & $0.023^{*}$ \\
\hline FGSI $v s$. WT and EC and R & 8.0587 & 0.1250 & -0.0247 & 0.2127 & 0.828 & 0.685 & 1.426 & 5.800 & $0.021^{*}$ \\
\hline FGSI vs. WT and EC and PP & 30.1354 & 0.5548 & -0.0520 & -1.6640 & 0.849 & 0.721 & 1.343 & 6.879 & $0.013^{*}$ \\
\hline FGSI vs. WT and EC and DP & -9.8010 & 0.5548 & -0.0520 & 1.6640 & 0.849 & 0.721 & 1.343 & 6.879 & $0.013^{*}$ \\
\hline FGSI vs. FSSI and EC & 16.4809 & 0.4355 & -0.0390 & - & 0.766 & 0.587 & 1.540 & 6.400 & $0.019^{*}$ \\
\hline FGSI vs. FSSI and $\mathrm{R}$ & -1.2306 & 0.6247 & 0.3564 & - & 0.747 & 0.558 & 1.594 & 5.670 & $0.026^{*}$ \\
\hline FGSI vs. FSSI and WT and EC & 16.0246 & 0.2607 & 0.0742 & -0.0410 & 0.780 & 0.609 & 1.590 & 4.148 & $0.048^{*}$ \\
\hline FGSI $v s$. FSSI and EC and R & 9.3167 & 0.5793 & -0.0240 & 0.1870 & 0.808 & 0.653 & 1.496 & 5.026 & $0.030^{*}$ \\
\hline
\end{tabular}

$\begin{array}{llll}\text { MGSI } & =\text { Male gonadosomatic index. } & \text { MSSI } & =\text { Male stomachsomatic index. } \\ \text { FGSI } & =\text { Female gonadosomatic index. } & \text { FSSI } & =\text { Female stomachsomatic index. } \\ \mathrm{a} & =\text { Constant. } & \mathrm{b} & =\text { Slope. } \\ \mathrm{SE} \mathrm{(b)} & =\text { Standard error of "b". } & \mathrm{r} & =\text { Correlation coefficient. } \\ \mathrm{r}^{2} & =\text { Coefficient of determination. } & \text { SEE } & =\text { Standard Error of the Estimate. } \\ F & =\text { F-value. } & P & =\text { Significance level. } \\ * & =\text { Correlation is significant at the } 0.05 \text { level (2-tailed). } & & =\text { Correlation is significant at the } 0.01 \text { level (2-tailed). }\end{array}$


By correlating them seasonally, SSI showed a negatively significant variation, especially for females than males, with either photoperiod or water temperature, when winter season was excluded. The relationships for these parameters appeared as follows:

For females:

And for males:

$$
\begin{aligned}
& \mathrm{SSI}=4.3446-0.0688 \mathrm{WT}\left(\mathrm{r}^{2}=0.974\right) \\
& \mathrm{SSI}=4.7708-0.1622 \mathrm{PP}\left(\mathrm{r}^{2}=0.996\right)
\end{aligned}
$$

$$
\begin{array}{ll}
\mathrm{SSI}=7.0773-0.2138 \mathrm{WT} & \left(\mathrm{r}^{2}=0.3648\right), \\
\mathrm{SSI}=10.1449-0.6532 \mathrm{PP} & \left(\mathrm{r}^{2}=0.5898\right) .
\end{array}
$$

Where $\mathrm{WT}=$ water temperature in centigrade, and $\mathrm{PP}=$ photoperiod in hours.

As indicated in Table (5), the univariate regression of monthly male GSI values and electrical conductivity (EC) was found to be negatively correlated $(\mathrm{P}<0.05)$. In addition, highly significant relationship $(\mathrm{P}<0.01)$ was obtained using the univariate analysis of male GSI versus rainfall. The male SSI was negatively significantly correlated $(\mathrm{P}<0.05)$ with rainfall. Also, highly significant negative relationship $(\mathrm{P}<$ $0.01)$ was obtained using the univariate analysis of female GSI versus electrical conductivity $(\mathrm{EC})$. Highly significant relationship $(\mathrm{P}<0.01)$ was obtained between female GSI and rainfall.

\section{DISCUSSION}

Similar to other vertebrates, many fish species are subject to a number of environmental challenges, which might have led to a number of feeding adaptations, such as coping with long-term fasting. In addition, seasonal changes in feeding often coincide with spawning, migration and reproduction, suggesting a link between nutrition and the reproductive axis (Volkoff et al., 2009). The spawning of a fish species is a subject to the innate characteristics moderated by the surrounding environmental factors (Khallaf and Al-ne-na-ei, 1987, 1993; Thomaz et al. 2007). M. kannume is no exception as revealed by the present results.

Thus, on examining GSI, maturity stages variation during the year months, two main distinctive periods were apparent with high activity. These periods extend from February-April and November-December, for either GSI or high occurrence of stage $\mathrm{V}$ of maturity for males, and more or less for females. However, since females have their peak in March that may be an indication that males stay active longer time than females till they commence spawning. Females also are found to have stage $\mathrm{V}$ of maturity during June, July and September, which is an indication of extended readiness to spawn most of the year months. Mature specimens (in stages IV and V) of both sexes were encountered throughout the months of the study period. This agreed with the findings of Scott (1974) and Fawole (2002) that most of the species of the family Mormyridae spawn more or less, throughout the year. Present results revealed that, there are no significant correlations between stage IV and V of both sexes and environmental factors. This is in agreement with the study of Kirschbaum (1987), on Pollimyrus isidori, that the relationship of the different stages of oocyte growth to the environmental changes could not be determined.

The feeding intensity of males that covered the months of May to September, and the slight rise in SSI of females indicate that the fish show low feeding activity at the times of spawning. The negative significant correlation $(P<0.01)$ (Table 3) between male GSI and SSI confirms this. Toguyeni et al. (1997) found that Oreochromis niloticus males increase their social interactions during sexual 
maturation, which could affect food intake. Bratton and Kramer (1989) mentioned that, in the male mormyrid fish, Pollimyrus isidori builds the nest, patrols his territory while searching for more nest materials and nudging the nest. Lamml and Kramer (2005) and Baier et al. (2006) reported that, in some mormyrids, reproduction was always indicated by highly conspicuous behaviours in male, such as marked territorial behaviour and nest building. In the African cichlid fish Astatotilapia (Haplochromis) burtoni, reproductively active territorial males spend all their time and energy in territory maintenance and mate attraction as well as sperm production (Hofmann et al., 1999; Hofmann, 2003). In addition, a decline in feeding is often seen during spawning, migrations or other reproductive behaviors (e.g., spawning, guarding) (van Ginneken and Maes, 2005; Volkoff et al., 2010). In both Atlantic cod (Fordham and Trippel, 1999) and winter flounder (Scott and Scott, 1988; MacDonald and Volkoff, 2009), feeding is suppressed in both sexes during the spawning period and increases after spawning.

The rise of occurrence of stage VI maturity of males during May, October and January, and January-February, May and August for females, is another proof that spawning occurs in the above mentioned periods. In accordance, Scott (1974), working on the same species in Uganda, indicated that M. kannume reproduction extends most of the year but with a conspicuous period of November to January, while ripe fish caught from October till June. However, Odoul (1986) from Kenya, defined the periods of April-May and November-December as the main spawning period for M. kannume. Similar findings were reported by El-Etreby (1985) on the fish from Lake Nasser and Aly (1993) on the fish from the High Dam reservoir. The previous studies of Authman and Khallaf (2009) and Khallaf and Authman (2009) on the spermatogenesis and oogenesis of $M$. kannume, respectively, from $\mathrm{BSC}$, are a further confirmation of the present results.

Males outnumbered females during May-August and December, and that could be attributed to that females are busy in a post spawning activity.

It is worth to mention that the temperature values of present study are higher than those recorded previously in BSC by Authman (1990), Elewa and Authman (1991) and Alne-na-ei (1999). Previously, Ashour et al. (1990a) suggested that the spawning of M. kannume is influenced by water temperature. The spawning behavior of M. kannume, as described in this study made it difficult to predict any significant correlation with either monthly average daily photoperiod or temperature (Table 5). Consequently, the coefficient of determination was negative and below $60 \%$. This is understandable, since the fish spawn in two main periods, one during summer and the second in winter that could be due to that M. kannume is a nocturnal fish (Hopkins, 1986; Kramer, 1990; Moller, 1995) and spawns during night (Kirschbaum and Schugardt, 2002). This was confirmed by the negative correlation between male GSI and photoperiod, while the negative correlation between female GSI and dark period is questionable. Previously, Khallaf et al. (1986) found some significant correlations between GSI of Tilapia nilotica and Tilapia zillii in BSC and water temperature and photoperiod.

On examining the relationship of SSI and the two examined environmental factors seasonally, females had a higher coefficient of determination $\left(r^{2}=>0.97\right)$ than males $\left(r^{2}=<0.59\right)$. This is attributed to the higher feeding intensity of females than males. As males become busy with spawning activity when daily temperature and photoperiod increase in most of the warmer and longer days, and hence they slow their feeding. There are positive correlations between male and female SSI and photoperiod and negative correlations between male and female SSI and dark period. 
This may be attributed to the fact that some fish appear to display a great plasticity in circadian rhythms as individual fish can be diurnal at first, then switch between diurnal and nocturnal activity (Reebs, 2002). Therefore, climate change when occurs, will have an eminent effect on that fish species reproduction and feeding.

The GSI of the fecund fish did not correlate significantly with either fish length $\left(r^{2}=0.48\right)$, or age $\left(r^{2}=0.44\right)$, due to the prolonged spawning season. During that period, females and males stay with different stages of maturity most of the time. That is understandable, since the fish mature at a length of $34 \mathrm{~cm}$ for females, and $36 \mathrm{~cm}$ for males, and $50 \%$ of the fish become mature at the length of $28 \mathrm{~cm}$ (2.33 years) and 30 ( 2.75 years) for females and males, respectively, as indicated by Khallaf and Authman (2010), while the fish length ranged from 29 to $53 \mathrm{~cm}$. It was also noted that fecundity and egg diameter correlate significantly with variation of length $\left(r^{2}=0.65\right)$ or age of the fish $\left(r^{2}=0.87\right)$, since those parameters are related to the ripe ova, while GSI is based on the weight of all immature and mature ova, thus variable.

The fish fecundity ranged between 393 and 10078 eggs with an average egg diameter of $1.96 \mathrm{~mm}$, while Fawole (2002), showed that the same species in Nigeria, produced between 741 and 6000 eggs, which can be attributed to variation in geographical differences. Adebisi (1987) found that, the fecundity of Marcusenius senegalensis in Ogun River, Nigeria, ranged between 830 and 1490 eggs, and the average egg diameter was $1.35 \mathrm{~mm}$, and he related the relatively low fecundities and large sizes of eggs of mormyrids to the existence of some degree of parental care. Albaret (1982) asserted that mormyrids of the rivers of Ivory Coast with low fecundities tend to hide their eggs in nests. Likewise, Coates (1988) suggested that the yolk content of fish eggs and hence their sizes, are closely linked to the degree of parental care accorded to the eggs and/or young.

It is evident from the present results that the male and female GSI were significantly negatively correlated with electrical conductivity (EC) (univariate regression). In addition, the multiple regressions of these variables versus EC and other environmental factors revealed a significant relationship with positive correlation coefficients (Table 5). On the other hand, significant positive relationships $(P<0.05)$ were obtained using the univariate and multivariate analyses of male and female GSI versus rainfall. This may lead to the conclusion that, the M. kannume GSI in BSC may be affected by the change in both electrical conductivity and the rainfall. Consistent with these observations, Bénech and Quensière (1985) have shown that in the Republic of Chad, the peak of reproduction in Pollimyrus isidori is preceded by a substantial decrease of conductivity and increase of water level, caused by the beginning of the rainy season. In that fish, gonadal recrudescence and regression are controlled by three environmental factors namely: conductivity, water level and rain (Kirschbaum, 1987). Schugardt and Kirschbaum (2004) concluded that decreasing conductivity is sufficient to induce complete gonadal maturation in mormyrids in experimental conditions as well as in the wild. Kirschbaum and Schugardt (2002) demonstrated that decrease of conductivity alone is sufficient to provoke complete gonad maturation. Kirschbaum (2000), Kirschbaum and Schugardt (2002) and Moller et al. (2004) mentioned that, in African freshwater mormyrid fishes, the environmental factors that control their cyclic reproduction are related to high water conditions, the most important cue being the decrease in water conductivity. Gonadal maturation could be induced by decreasing conductivity, increasing water level and rainfall (high water conditions), while gonadal regression could be caused by increasing conductivity (low water conditions) alone (Schugardt and Kirschbaum, 2004). Which sensory systems would allow mormyrid fishes to measure conductivity 
changes? There are indications that mormyrids might be able to use their electrosensory system for this purpose (Moller 1995; Schugardt and Kirschbaum, 2004). African freshwater mormyrid fishes generate and perceive electric organ discharges (EODs) that are involved in social contact and communication, territorial behaviour, prey detection, individual recognition, nocturnal courtship and mating (Hopkins, 1986; Kramer, 1990, 1996; Moller 1995; Kramer et al., 2003, 2004).

\section{CONCLUSION}

The present results revealed no obvious correlation between fish reproduction, and either temperature or photoperiod. However, under natural conditions, these parameters are difficult to separate, and act collectively with other environmental factors as shown by multivariate analyses. On the other hand, electrical conductivity and rainfall significantly affect on the reproduction of the fish. Therefore, the present data indicate that $M$. kannume is susceptible for global warming effects.

\section{REFERENCES}

Adebisi, A.A. (1987). The relationship between the fecundities, gonadosomatic indices and egg sizes of some fishes of Ogun River, Nigeria. Arch. Hydrobiol., 111(1): 151-156.

Albaret, J.J. (1982). Reprduction et fecundite despoissons, d'eau douce de Cote d'lvoire. Rev. Hydrobiol., 15(4):347-371.

Albritton, D.L.; Meira Filho, L.G.; Cubasch, U.; Dai, X.; Ding, Y.; Griggs, D.J.; Hewitson, B.; Houghton, J.T.; Isaksen, I.; Karl, T.; McFarland, M.; Meleshko, V.P.; Mitchell, J.F.B.; Noguer, M.; Nyenzi, B.S.; Oppenheimer, M.; Penner, J.E.; Pollonais, S.; Stocker, T. and Trenberth, K.E. (2001): Technical Summary, in: Houghton, J.T.; Ding, Y.; Griggs, D.J.; Noguer, M.; van der Linden, P.J.; Dai, X.; Maskell, K. and Johnson, C.A. (Eds.), Climate Change 2001. The Scientific Basis. Contribution of Working Group I to the Third Assessment Report of the Intergovernmental Panel on Climate Change. Cambridge University Press, Cambridge, UK and New York, USA, 881pp.

Alne-na-ei, A.A. (1999). Biology of the freshwater fish, Pollimyrus isidori (Valenciennes, 1846) (Teleostei, Mormyridae) in the River Nile Delta. Egypt. J. Aquat. Biol. \& Fish., 3(1): 195-222.

Aly, A.M. (1993). Biological studies on mormyrid fishes of the High Dam reservoir. M. Sc. Thesis, Fac. Sci. Aswan, Assiut University, Egypt, $101 \mathrm{pp}$.

Ashour, M.B.; Zaher, M.M. and Rida, S. (1990a). Ecological studies on the female reproductive cycle of some fishes of the River Nile at Beni Suef Area. I. Seasonal variation in the size of the eggs in the ovaries of Mormyerus kannume, Chrysichthys auratus and Schilbe mystus. J. Egypt. Ger. Soc. Zool., 2: 273-286.

Ashour, M.B.; Zaher, M.M. and Rida, S. (1990b). Ecological studies on the female reproductive cycle of some fishes of the River Nile at Beni Suef Area. II. Histological analysis of the seasonal cycle of the ovary of Mormyerus kannume. J. Egypt. Ger. Soc. Zool., 2: 347-360.

Authman, M.M.N. (1990). Studies on some biological aspects of Bagrus bayad (Family: Bagridae) from Bahr Shebeen Canal. M. Sc. Thesis, Zool. Dept., Fac. Sci., Menoufia Univ., Egypt, 169pp.

Authman, M.M.N. and Khallaf, E.A. (2009). Spermatogenesis of Male Mormyrus kannume (Forsskål, 1775) (Teleostei: Mormyridae) from Bahr Shebeen Nilotic Canal, Delta, Egypt. Egypt. J. Aquat. Biol. \& Fish., 13(4): 361-384.

Bagenal, T.B. (1978). Aspects of the fish fecundity. pp.: 75-101. In: Gerking, S.D. (Ed.), Ecology of freshwater fish production. Blackwell Sci. Publ. Oxford, England.

Bagenal, T.B. and Tesch, F.W. (1978). Age and growth. pp.: 101-136. In: Bagenal, T.B. (Ed.), Methods for assessment of fish production in fresh waters, $3^{\text {rd }}$ edn. IBP 
Handbook No. 3, Blackwell Scientific Publication, Oxford, UK.

Baggerman, B. (1980). Photoperiod and endogenous control of the annual reproductive cycle in teleost fishes. pp.: 533-567. In: Ali, M.A. (Ed.), Environmental Physiology of Fishes. Plenum Press, New York, USA.

Baier, B.; Lamml, M. and Kramer, B. (2006). Ontogeny of the electric organ discharge in two parapatric species of the dwarf stonebasher, Pollimyrus castelnaui and P. Marianne (Mormyridae, Teleostei). Acta Zoologica (Stockholm), 87: 209-214.

Ballagh, D.A.; Pankhurst, P.M. and Fielder, D.S. (2008). Photoperiod and feeding interval requirements of juvenile mulloway, Argyrosomus japonicus. Aquacult., 277: 52-57.

Bénech, V. and Quensière, J. (1985). Stratégies de reproduction des poissons du Tchad en période de 'Tchad Normal' (1966-1971). Rev. Hydrobiol. Trop. Paris, 18: 227-244.

Bhikajee, M. and Gobin, P. (1998). Effect of temperature on the feeding rate and growth of a red tilapia hybrid. Tilapia Aquacult. Proceedings from the $4^{\text {th }}$ International Symposium on Tilapia Aquacult., 1: 131-140.

Billard, R. (1982). The reproductive cycle in teleost fish, Riv. It. Piscic. Ittiop., A8(2): 48-64.

Bishai, H.M. and Khalil, M.T. (Eds.) (1997). Freshwater fishes of Egypt. Egyptian Environmental Affairs Agency (EEAA), Cabinet of Ministers, Egypt, Department of Nature Protection. Publication of National Biodiversity Unit, No. 9: 229pp.

Biswas, A.K. and Takeuchi, T. (2002). Effect of different photoperiod cycles on metabolic rate and energy loss of both fed and unfed adult tilapia Oreochromis niloticus: Part II. Fish. Sci., 68: 543-553.

Biswas, A.K.; Endo, M. and Takeuchi, T. (2002). Effect of different photoperiod cycles on metabolic rate and energy loss of both fed and unfed young tilapia Oreochromis niloticus: Part I. Fish. Sci., 68: 465-477.

Biswas, A.K.; Morita, T.; Yoshizaki, G.; Maita, M. and Takeuchi, T. (2005a). Control of reproduction in Nile tilapia Oreochromis niloticus (L.) by photoperiod manipulation. Aquacult., 243: 229-239.

Biswas, A.K.; Seoka, M.; Inoue, Y.; Takii, K. and Kumai, H. (2005b). Photoperiod influences the growth, food intake, feed efficiency and digestibility of red sea bream (Pagrus major). Aquacult., 250: 666-673.

Boeuf, G. and Le Bail, P.Y. (1999). Does light have an influence on fish growth? Aquacult., 177: 129-152.

Bolliet, V.; Aranda, A. and Boujard, T. (2001). Demand-feeding rhythm in rainbow trout and European catfish Synchronisation by photoperiod and food availability. Phys. Behav., 73: 625-633.

Boulenger, G.A. (1907). Zoology of Egypt: The Fishes of the Nile. Published for the Egyptian Government by Hugh Rees Ltd., London, liii+1-578+XCVII.

Bratton, B.O. and Kramer, B. (1989). Patterns of the electric organ discharge during courtship and spawning in the mormyrid fish, Pollimyrus isidori. Behav. Ecol. Sociobiol., 24: 349-368.

Breton, B.; Horoszewicz, L.; Bieniarz, K. and Epler, P. (1980a). Temperature and reproduction in tench: Effect of a rise in the annual temperature regime on gonadotropin level, gametogenesis and spawning. I. The male. Reprod. Nutr. Dev., 20: 105-118.

Breton, B.; Horoszewicz, L.; Bieniarz, K. and Epler, P. (1980b). Temperature and reproduction in tench: Effect of a rise in the annual temperature regime on gonadotropin level, gametogenesis and spawning. II. The female. Reprod. Nutr. Dev., 20: 1011-1024.

Brett, J.R. (1979). Environmental factors and growth. pp.: 599-677. In: Hoar, W.S.; Randall, D.J. and Brett, J.R. (Eds.), Fish Physiology, VIII: Bioenergetics and Growth. Academic Press, London and New York.

Bromage, N.R.; Porter, M. and Randall, C.F. (2001). The environmental regulation of maturation in farmed finfish with special reference to the role of photoperiod and melatonin. Aquacult., 197: 63-98.

Buentello, J.A.; Gatlin III, D.M. and Neill, W.H. (2000). Effects of water temperature and dissolved oxygen on daily feed consumption, feed utilization and growth of channel catfish Ictalurus punctatus. Aquacult., 182: 339-352. 
Cicerone, R.J.; Barron, E.J.; Dickinson, R.E.; Fung, I.Y.; Hansen, J.E.; Karl, T.R.; Lindzen, R.S.; McWilliams, J.C.; Rowland, F.S.; Sarachik, E.S. and Wallace, J.M. (2001). Climate Change Science: An Analysis of Some Key Questions. Committee on the Science of Climate Change, Division of Earth and Life Studies, National Research Council, National Academy Press, Washington, USA.

Coates, D. (1988). Length-dependent changes in egg size and fecundity in females, and brooded embryo size in males, of fork-tailed catfishes (Pisces: Ariidae) from the Sepik River, Papua New Guinea, with some implications for stock assessment. J. Fish Biol., 33(3): 455-464.

De Vlaming, V.L. (1972). Environmental control of teleost reproductive cycles: a brief review. J. Fish Biol., 4: 131-140.

Duncan, D. B. (1955). Multiple range and multiple F-test. Biometrics, 11: 1-42.

Duston, J. and Saunders, R.L. (1990). The entrainment role of photoperiod on hypoosmoregulatory and growth-related aspects of smolting in Atlantic salmon (Salmo salar). Can. J. Zool., 68: 707-715.

Dutta, H. (1994). Growth in Fishes. In: Pisces. Gerontology, 40: 97-112.

El-Etreby, S.G. (1985). Biological studies on Mormyrus kannume Forsk. in Lake Nasser. I. Distribution, Age, Growth and Breeding. First Int. Conf. App. Sci., Zagazig Univ., Egypt, 30 March-1 April, 4: 93-120.

El-Etreby, S.G. (1986). Biological studies on Mormyrus kannume Forsk. in Lake Nasser. II. Cyclical changes in the gonads. Egypt. J. Histol., 9(2): 321-327.

Elewa, A.A. and Authman, M. (1991). Limnological studies on Bahr Shebeen Canal, ElMenoufia Governorate, Egypt. Bull. Fac. Sci., Zagazig Univ., Egypt, 13(2): 470-480.

Elliott, J.M. (1982). The effects of temperature and ration size on the growth and energetics of salmonids in captivity. Comp. Biochem. Physiol., 73B: 81-91.

El-Sayed, A.F.M. and Kawanna, M. (2004). Effects of photoperiod on the performance of farmed Nile tilapia Oreochromis niloticus: I. Growth, feed utilization efficiency and survival of fry and fingerlings. Aquacult., 231: 393-402.

Fawole, O.O. (2002). Morphometry and diet of Mormyrus rume in the Lekki lagoon, Nigeria. Rev. Biol. Trop., 50(2): 689-694.

Fordham, S.E. and Trippel, E.A. (1999). Feeding behaviour of cod (Gadus morhua) in relation to spawning. J. Appl. Ichthyol., 15: 1-9.

Forsskål, P. (1775). Descriptiones animalium avium, amphibiorum, piscium, insectorum, vermium; quae in itinere orientali observavit Petrus Forsskål. Post mortem auctoris edidit Carsten Niebuhr. Hauniae. Descr. Animalium, 1-20 + i-xxxiv + 1-164.

Gosse, J.P. (1984). Mormyridae, Gymnarchidae. pp.: 63-122. In: Daget, J.; Gosse, J.P. and Thys van den Audenaerde, D.F.E. (Eds.), Check-list of the freshwater fishes of Africa (CLOFFA). ORSTOM, Paris and MRAC, Tervuren, Vol. 1.

Gross, W.L.; Roelofs, E.W. and Fromm, P.O. (1995). Influence of photoperiod on growth of green sunfish, Lepomis cyanellus. J. Fish. Res. Board Can., 22: 1379-1386.

Hassan, A.A. (2007). Studies on population dynamics of two freshwater fish species: Synodontis schall and Mormyrus kannume from the Nile at Assiut, Egypt. M. Sc. Thesis, Department of Zoology, Faculty of Science, Assiut University, Assiut, Egypt, $212 p$.

Hay, C.J.; Van Zyl, B.J. and Steyn, G.J. (1996). A quantitative assessment of the biotic integrity of the Okavango river, Namibia based on fish. Wat. SA, 22: 263-284.

Hofmann, H.A. (2003). Functional Genomics of Neural and Behavioral Plasticity. J. Neurobiol., 54: 272-282.

Hofmann, H.A.; Benson, M.E. and Fernald, R.D. (1999). Social status regulates growth rate: consequences for life-history strategies. Proc. Natl. Acad. Sci. USA, 96: 14171-14176.

Hopkins, C.D. (1981). On the diversity of electric signals in a community of mormyrid electric fish in West Africa. Amer. Zool., 21: 211-222.

Hopkins, C.D. (1986). Behavior of Mormyridae. pp.: 527-576. In: Bullock, T.H. and Heiligenberg, W. (Eds.), Electroreception. John Wiley \& Sons, New York, USA.

Huber, M. and Bengtson, D.A. (1999). Effects of photoperiod and temperature on the 
regulation of the onset of maturation in the estuarine fish Menidia beryllina (Cope) (Atherinidae). J. Exp. Mar. Biol. Ecol., 240: 285-302.

Hugh Copley, O.B.E. (1958). Common Freshwater Fishes of East Africa. H. F. \& G. Witherby Ltd., London, 172p.

Hugueny, B.; Camara, S.; Samoura, B. and Magassouba, M. (1996). Applying an index of biotic integrity based on fish assemblages in a West African river. Hydrobiologia, 331: 71-78.

Jin, Y.; Shu, L.; Sun, L.; Liu, W. and Fu, Z. (2010). Temperature and photoperiod affect the endocrine disruption effects of ethinylestradiol, nonylphenol and their binary mixture in zebrafish (Danio rerio). Comp. Biochem. Physiol., C151: 258-263.

Khallaf, E.A. (2002). An ecological assessment of Bahr Shebeen Canal (Review paper). J. Union Arab Biol., Cairo, 17(A): 65-75.

Khallaf, E.A. and Alne-na-ei, A.A. (1987). Feeding ecology of Oreochromis niloticus (Linnaeus) and Tilapia zillii (Gervias) in a Nile canal. Hydrobiologia, 146: 57-62.

Khallaf, E.A. and Alne-na-ei, A.A. (1993). Feeding ecology of Barbus bynni (Forskal) from Bahr Shebeen Canal. Arch. Hydrobiol., 90(4): 575-587.

Khallaf, E.A. and Authman, M.N. (1992). Changes in diet, prey size and feeding habit in Bagrus bayad, and possible interactions with B. docmac in a Nile canal. Environ. Biol. Fish., 34(4): 425-431.

Khallaf, E.A.H. and Authman, M.M.N. (2009). Oogenesis of Females of the Nile Mormyrid Fish, Mormyrus kannume (Forsskål, 1775) from Bahr Shebeen Canal, Egypt. Egypt. J. Aquat. Biol. \& Fish., 13(4): 333-359.

Khallaf, E.A.H. and Authman, M.M.N. (2010). Some biological aspects of the Nile Mormyrid Fish, Mormyrus kannume (Forsskål, 1775) from Bahr Shebeen Nilotic Canal, Egypt. World J. Fish Mar. Sci., 2(5): 357-375.

Khallaf, E.A.; Galal, M. and Authman, M. (2003). The biology of Oreochromis niloticus in a polluted canal. Ecotoxicology, 12: 405-416.

Khallaf, E.A.; Latif, A.F.A. and Alne-na-ei, A.A. (1986). Reproduction of Tilapia nilotica and T. zillii in a Nile Canal and its interaction with the environment. Delta J. Sci., Egypt, 10(2): 724-747.

Kirschbaum, F. (1987). Reproduction and development of the weakly electric fish, Pollimyrus isidori (Mormyridae, Teleostei) in captivity. Environ. Biol. Fish., 20(1): 11-31.

Kirschbaum, F. (2000). The breeding of tropical freshwater fishes through experimental variation of exogenous parameters, Aqua Geografica, 20: 95-107.

Kirschbaum, F. and Schugardt, C. (2002). Reproductive strategies and developmental aspects in mormyrid and gymnotiform fishes. J. Physiol. Paris, 96: 557-566.

Kouamélan, P.E.; Teugels, G.G.; Gourène, G.; Ollevier, F. and Thys van den Audenaerde, D.F.E. (1999). The effect of a man-made lake on the diet of the African electric fish Mormyrus rume Valenciennes, 1846 (Osteoglossiformes; Mormyridae). Hydrobiologia, 380: 141-151.

Kramer, B. (1990). Electrocommunication in Teleost Fishes: Behavior and Experiments. Springer, New York, 240pp.

Kramer, B. (1996). Electroreception and Communication in Fishes. Progress in Zoology Vol. 42, Gustav Fischer Verlag, Stuttgart, 119pp.

Kramer, B.; van Der Bank, H. and Wink, M. (2004): Hippopotamyrus ansorgii species complex in the Upper Zambezi River System with a description of a new species, $H$. szaboi (Mormyridae). The Norwegian Academy of Science and Letters, Zoologica Scripta, 33(1): 1-18.

Kramer, B.; van der Bank, H.; Flint, N.; Sauer-Gürth, H. and Wink, M. (2003). Evidence for parapatric speciation in the Mormyrid fish, Pollimyrus castelnaui (Boulenger, 1911), from the Okavango-Upper Zambezi River Systems: P. marianne sp. nov., defined by electric organ discharges, morphology and genetics. Environ. Biol. Fish., 77: 47-70.

Lamml, M. and Kramer, B. (2005). Sound production in the reproductive behaviour of the weakly electric fish Pollimyrus marianne Kramer et al. 2003 (Mormyridae, Teleostei). Bioacoustics, 15(1): 51-78. 
Latif, A.F.A. (1974). Fisheries of Lake Nasser. Aswan Regional Planning, Lake Nasser Development Centre, Aswan, Egypt, 235pp.

Lewis, J.W.; Kay, A.N. and Hanna, N.S. (1992a). Responses of the electric fish Gnathonemus tamandua (Family Mormyridae) to changes in pH. Environ. Technol., 13: 701-705.

Lewis, J.W.; Kay, A.N. and Hanna, N.S. (1992b). Responses of electric fish (Family Mormyridae) to chemical changes in water quality: I. Cyanide. Environ. Technol., 13: $1169-1174$.

Lewis, J.W.; Kay, A.N. and Hanna, N.S. (1993). Responses of electric fish (Family Mormyridae) to chemical changes in water quality: 1I. Pesticides. Environ. Technol., 14: 1171-1178.

Lewis, J.W.; Kay, A.N. and Hanna, N.S. (1994). Responses of electric fish (Family Mormyridae) to chemical changes in water quality: III. Heavy Metals. Environ. Technol., 15: 969-978.

Lewis, J.W.; Kay, A.N. and Hanna, N.S. (1995). Responses of electric fish (Family Mormyridae) to inorganic nutrients and tributyltin oxide. Chemosphere, 31(7): 37533769.

Lukšienè, D. and Svedäng, H. (1997). A review on fish reproduction with special reference to temperature anomalies. Fiskeriverket, Kustlaboratoriet, Gamla Slipvägen 19, 74071 Öregrund, 35p.

MacDonald, E. and Volkoff, H. (2009). Cloning, distribution and effects of season and nutritional status on the expression of neuropeptide Y (NPY), cocaine and amphetamine regulated transcript (CART) and cholecystokinin (CCK) in winter flounder (Pseudopleuronectes americanus). Horm. Behav., 56: 58-65.

Meisner, J.D.; Rosenfeld, J.S. and Regier, H.A. (1988). The role of groundwater in the impact of climate warming on stream salmonines. Fisheries, 13: 2-8.

Moller, P. (1995). Electric Fishes: History and Behaviour. Fish \& Fisheries Series 17, Chapman \& Hall, London, New York, 584p.

Moller, P.; Schugardt, C. and Kirschbaum, F. (2004). Permanent and seasonal expressions of sexual dimorphisms in a weakly electric fish, Mormyrus rume proboscirostris Boulenger 1898 (Mormyridae, Teleostei). Environ. Biol. Fish., 70: 175-184.

O'Neal, K. (2002). Effects of Global Warming on Trout and Salmon in U.S. Streams. Defenders of Wildlife \& Natural Resources Defense Council, USA, 44p.

Odoul, C.H.O. (1986). The biology of a mormyrid fish Mormyrus kannume (Forsskal 1776) in tropical Man-made Lake, Lake Kamburu. M. Sc., University of Nairobi, Kenya. www. ResearchKenya.org.

Oliveira, C.; Mañanós, E.; Ramos, J. and Sánchez-Vázquez, F.J. (2011). Impact of photoperiod manipulation on day/night changes in melatonin, sex steroids and vitellogenin plasma levels and spawning rhythms in Senegal sole, Solea senegalensis. Comp. Biochem. Physiol., A159: 291-295.

Pankhurst, N.W.; Purser, G.J.; Van Der Kraak, G.; Thomas, P.M. and Forteath, G.N.R. (1996). Effect of holding temperature on ovulation, egg fertility, plasma levels of reproductive hormones and in vitro ovarian steroidogenesis in the rainbow trout Oncorhynchus mykiss. Aquacult., 146: 277-290.

Rad, F.; Bozaoğlu, S.; Gözükara, S.E.; Karahan, A. and Kurt, G. (2006). Effects of different long-day photoperiods on somatic growth and gonadal development in Nile tilapia (Oreochromis niloticus L.). Aquacult., 255: 292-300.

Reebs, S.G. (2002). Plasticity of diel and circadian activity rhythms in fishes. Rev. Fish Biol. Fish., 12: 349-371.

Schugardt, C. and Kirschbaum, F. (2004). Control of gonadal maturation and regression by experimental variation of environmental factors in the mormyrid fish, Mormyrus rume proboscirostris. Environ. Biol. Fish., 70: 227-233.

Scott, D.B.C. (1974). The reproductive cycle of Mormyrus kannume Forsk. (Osteoglossomorpha, Mormyriformes) in Lake Victoria, Uganda. J. Fish Biol., 6(4): 447-454.

Scott, W.B. and Scott, M.G. (1988). Atlantic Fishes of Canada. University of Toronto Press, 
Canada, 730p.

Silva-Garcia, A.J. (1996). Growth of juvenile gilthead seabraem (Sparus auratus L.) reared under different photoperiod regimes. Israeli J. Aquacult., Bamidgeh, 48: 84-93.

Soliman, F.M. (1994). Studies on some biological aspects of Mormyrus kannume, Forskal in the River Nile at Sohag Governorate, Upper Egypt. Bull. Fac. Sci., Assiut Univ., Egypt, 23(2-E): 83-99.

Stefan, H.G. and Preud'homme, E.B. (1993). Stream temperature estimation from air temperature. Wat. Resour. Bull., 29(1): 1-19.

Taylor, J.F.; North, B.P.; Porter, M.J.R.; Bromage, N.R. and Migaud, H. (2006). Photoperiod can be used to enhance growth and improve feeding efficiency in farmed rainbow trout, Oncorhynchus mykiss. Aquacult., 256: 216-234.

Taylor, J.F.; Porter, M.J.R.; Bromage, N.R. and Migaud, H. (2008). Relationships between environmental changes, maturity, growth rate and plasma insulin-like growth factor-I (IGF-I) in female rainbow trout. Gen. Comp. Endocrinol., 155: 257-270.

Thomaz, S.M.; Bini, L.M. and Bozelli, R.L. (2007). Floods increase similarity among aquatic habitats in river-floodplain systems. Hydrobiologia, 579: 1-13.

Toguyeni, A.; Fauconneau, B.; Boujard, T.; Fostier, A.; Kuhn, E.R.; Mol, K.A. and Baroiller, J.F. (1997). Feeding Behaviour and Food Utilisation in Tilapia, Oreochromis niloticus: Effect of Sex Ratio and Relationship with the Endocrine Status. Phys. Behav., 62(2): 273-279.

Trippel, E.A. and Neil, S.R.E. (2002). Effect of photoperiod and light intensity on growth and activity of juvenile haddock (Melanogrammus aeglefinus). Aquacult., 217: 633-645.

van der Sluijs, I.; Gray, S.M.; Amorim, M.C.P.; Barber, I.; Candolin, U.; Hendry, A.P.; Krahe, R; Maan, M.E.; Utne-Palm, A.C.; Wagner, H.J. and Wong, B.B.M. (2011). Communication in troubled waters: responses of fish communication systems to changing environments. Evol. Ecol., 25: 623-640.

van Ginneken, V.J.T. and Maes, G.E. (2005). The European eel (Anguilla anguilla, Linnaeus), its lifecycle, evolution and reproduction: a literature review. Rev. Fish Biol. Fish., 15: 367-398.

Volkoff, H.; Hoskins, L.J. and Tuziak, S.M. (2010). Influence of intrinsic signals and environmental cues on the endocrine control of feeding in fish: Potential application in Aquacult.. Gen. Comp. Endocrinol., 167: 352-359.

Volkoff, H.; Xu, M.; MacDonald, E. and Hoskins, L. (2009). Aspects of the hormonal regulation of appetite in fish with emphasis on goldfish, Atlantic cod and winter flounder: Notes on actions and responses to nutritional, environmental and reproductive changes. Comp. Biochem. Physiol., A153: 8-12.

Webb, J.E.; Wallwork, J.A. and Elgood, J.H. (1981). Guide to living fishes. The American Press LTD, London and Basingstoke, 181p.

Wilkinson, R.J.; Longland, R.; Woolcott, H. and Porter, M.J.R. (2010). Effect of elevated winter-spring water temperature on sexual maturation in photoperiod manipulated stocks of rainbow trout (Oncorhynchus mykiss). Aquacult., 309: 236-244.

Zaher, M.M.; Ashour, M.B. and Rida, S. (1991). Ecological studies on the female reproductive cycle of some fishes of the River Nile at Beni Seuf area "Seasonal morphological and macroscopic changes of the ovary of Mormyerus Kannume, Chrysichthyes auratus and Schilbe mystus. J. Egypt. Ger. Soc. Zool., 3: 313-334. 

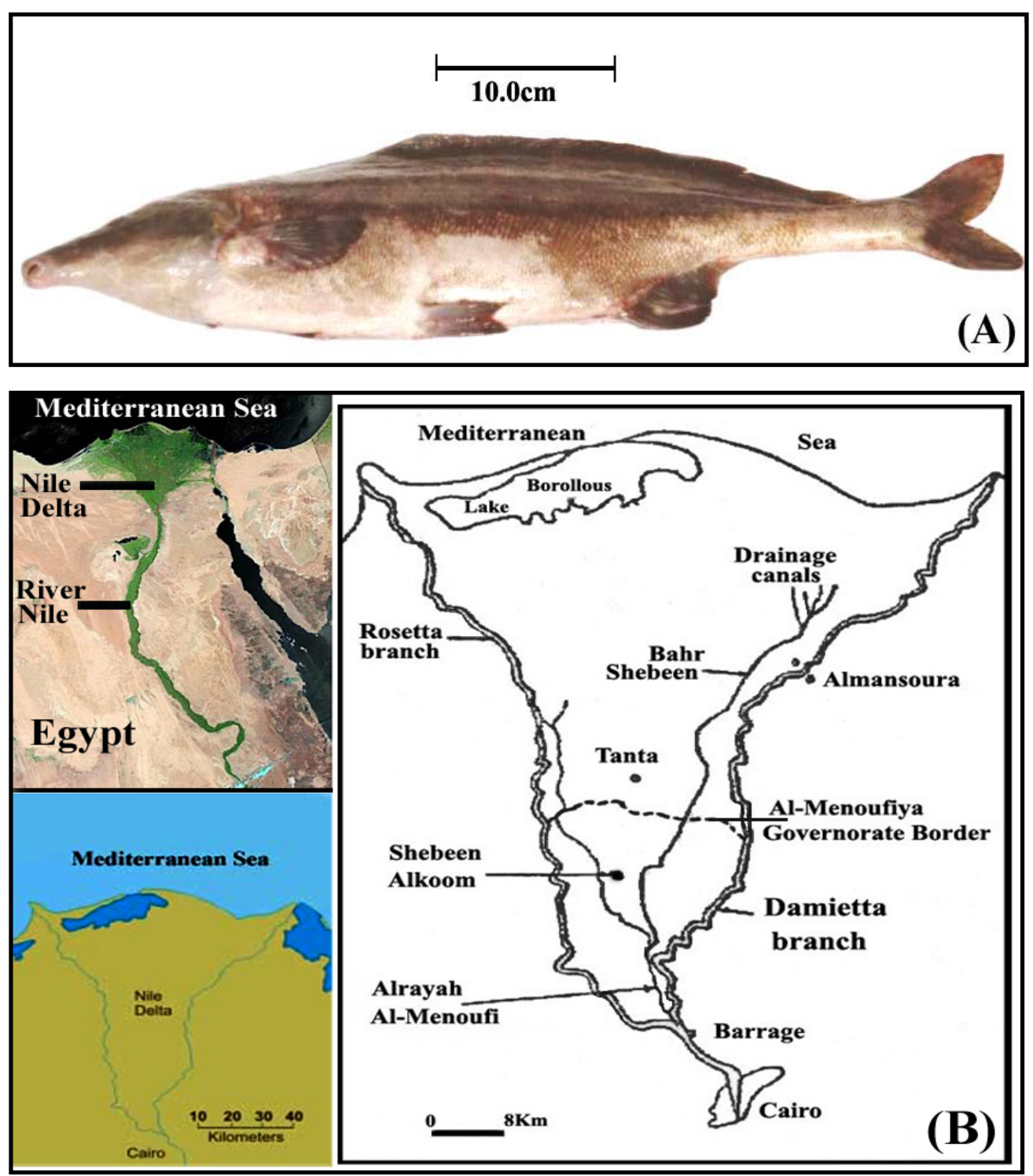

Fig. 1: (A) M. kannume, $57.9 \mathrm{~cm}$ total length, (B) Map of Nile Delta showing Bahr Shebeen Canal (BSC). 


\title{
ARABIC SUMMARY
}

\section{التفاعل بين التكاثر وكثافة الإغتذاء فى أسماك الأنومة مورمبرس كانوم (فورسكال 1775) و البيئة فى قناة نيلية، مصر الأوملة فورير}

\section{السيد أحمد حسن خلاف1 و محمد محمود نبيه عثمان2}

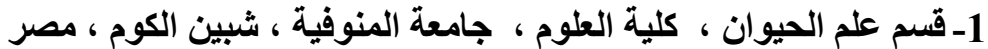

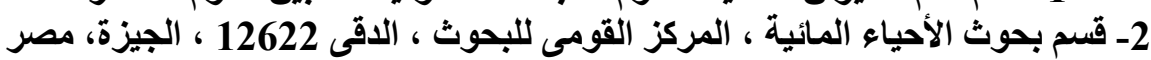

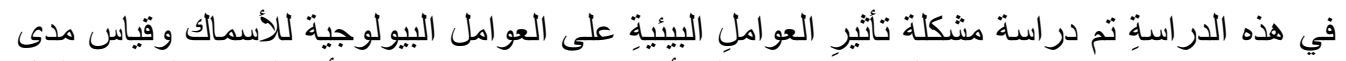

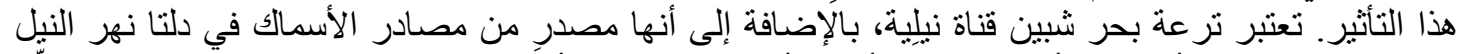

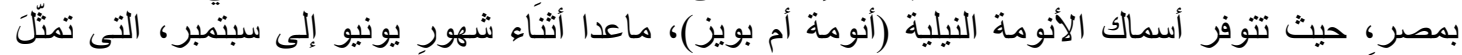

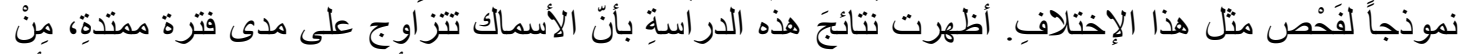

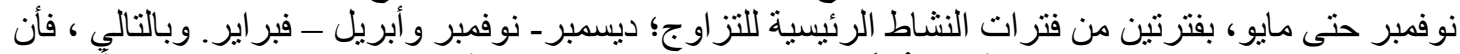

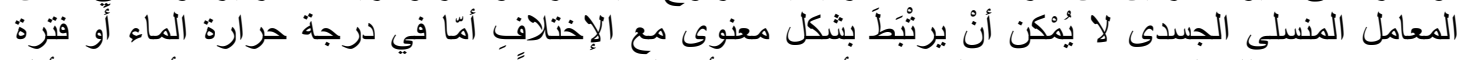

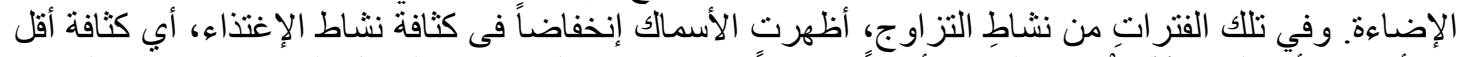

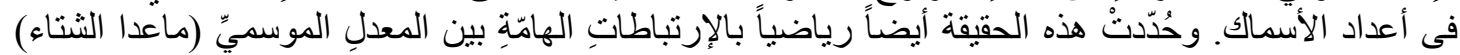

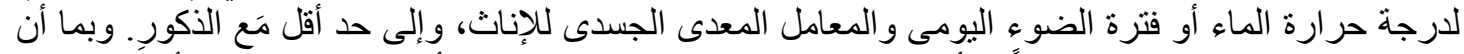

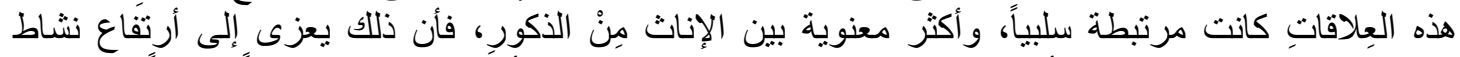

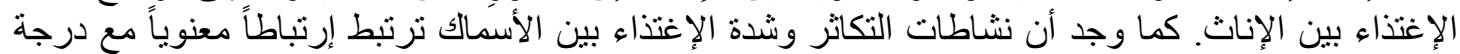

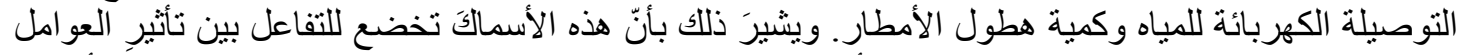

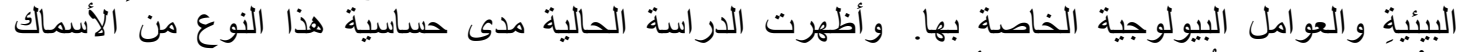

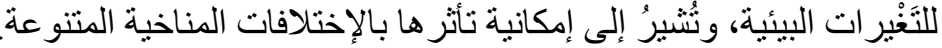

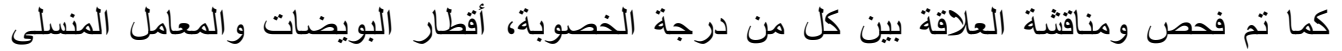
الجسدى وطول و عمر إناث هذا النوع من الأسماك، ووَصْف الإرنباطاتِ الرياضيةِ بينها. 